\title{
CONTANDO HISTÓRIAS, RESGATANDO MEMÓRIAS: ARTE COMO MEDIADORA PARA O RESGATE DE TRAJETÓRIAS E MEMÓRIAS DE CRIANÇAS MIGRANTES
}

\author{
Telling Stories, Recovering Memories: Art As A Mediation To Recover \\ Migrant Children's Paths And Memories
}

Graziela Lucchesi Rosa da SILVA

Universidade Federal do Paraná grazielaluc@ufpr.br http://orcid.org/0000-0002-5424-2780

Camila Akemi AOTO Universidade Federal do Paraná milaaoto@gmail.com http://orcid.org/0000-0002-8947-459X

Luana LUBKE Universidade Estadual de Ponta Grossa luanalubke@gmail.com http://orcid.org/0000-0001-6090-2768

Luisa Martins de ABREU E LIMA Universidade Federal do Paraná luisa.abreuelima@gmail.com http://orcid.org/0000-0002-3948-3615

Maria GABRIEL Universidade Federal do Paraná mgabriel.ufpr@gmail.com http://orcid.org/0000-0003-4676-1609

Mayssun Omari OSMAN Universidade Federal do Paraná mayssun.osman@gmail.com http://orcid.org/0000-0003-1616-714X

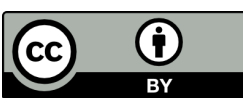




\author{
Nathalia TSIFLIDIS \\ Universidade Federal do Paraná \\ nathaliatsiflidis@tutanota.com \\ http://orcid.org/0000-0001-6606-6836 \\ Victória de Biassio KLEPA \\ Universidade Federal do Paraná \\ vbklepa@gmail.com \\ http://orcid.org/0000-0002-6310-4160
}

RESUMO: Ante o contexto migratório contemporâneo, é fundamental a elaboração de ações promotoras de desenvolvimento voltadas às especificidades da infância, considerando os impactos do deslocamento forçado nesse período da vida. Sob tal direção, a ação extensionista Pequenos do Mundo, da Universidade Federal do Paraná (UFPR), foi elaborada. No presente artigo, apresentamos e discutimos, a partir dos fundamentos da Psicologia Histórico-Cultural, a metodologia desenvolvida, valendo-se da arte em suas diferentes expressões e manifestações para o resgate e a valorização das memórias afetivas das crianças e de suas famílias, sobre cultura de origem, trajetórias e vivências. Em contraposição a um apagamento cultural sofrido em migrações involuntárias, desenvolvemos uma proposta e consequentes ações em que as crianças pudessem ouvir histórias, contar as suas e, nesse processo, se reconhecerem e reconhecerem os outros. As ações possibilitaram a elaboração simbólica e material sobre processos culturais e identitários, e, nesse processo, as crianças tomam posse para si de uma ferramenta que promove o resgate e o compartilhamento de aspectos da sua relação com seus pares e com o meio, apropriando-se e transformando suas histórias. PALAVRAS-CHAVE: Infância; Migração; Memórias Afetivas; Psicologia Histórico-Cultural.

\begin{abstract}
In view of the contemporary migratory context, it is essential to elaborate actions that promote development aimed at the specificities of childhood, considering the impacts of forced displacement in this period of life. Under such direction, the extension action Pequenos do Mundo, from the Federal University of Paraná (UFPR), was elaborated. In the present study, we present and discuss, based on the foundations of Historical-Cultural Psychology, the methodology developed, making use of art in its different expressions and manifestations to rescue and enhance the affective memories of children and their families, about their original culture, paths and experiences. In contrast to a cultural erasure suffered in involuntary migrations, we developed a proposal and consequent actions in which children could hear stories, tell theirs and, in the process, recognize themselves and
\end{abstract}


others. The actions enabled the symbolic and material elaboration on cultural and identity processes, and, in this process, children take possession of a tool that promotes the rescue and sharing of aspects of their relationship with their peers and with the environment, playing a leading role in their own lives and in transforming their stories. KEYWORDS: Childhood; Migration; Affective memories; Historical-Cultural Psychology

\section{MIGRAÇÕES CONTEMPORÂNEAS E INFÂNCIA}

Segundo o Alto Comissariado das Nações Unidas para Refugiados (ACNUR), no fim de 2019 foi registrado o maior número de pessoas já deslocadas involuntariamente: 79,5 milhões (ACNUR, 2020). Este dado reflete a dramaticidade vivenciada no contexto atual em relação ao movimento migratório ao considerarmos os motivos e as consequências desse deslocamento involuntário. Se, por um lado, a perseguição em função de raça, religião, nacionalidade, opiniões políticas ou por crises políticas e econômicas (OIM, 2019) forçam o deslocamento; por outro, a xenofobia, o preconceito e a racialização são comumente vivenciados pelas pessoas que migram para outros países. As crianças e adolescentes não são preservadas destas situações; pelo contrário: são fortemente afetadas pelo não acolhimento, pela invisibilidade cotidiana, pelo embrutecimento das potencialidades, pela patologização do desenvolvimento e pelo apagamento cultural.

No mundo, segundo a ACNUR, estima-se que cerca de $40 \%$ das pessoas que se deslocaram em 2019 (entre 30 e 34 milhões) eram crianças e adolescentes; dessas, dezenas de milhares estavam desacompanhadas ou separadas de suas famílias (ACNUR, 2020). Dados do Fundo das Nações Unidas para a Infância (UNICEF) apontam que o número de crianças migrantes e refugiadas aumentou de 24 milhões durante 1990-2000 para 33 milhões em 2019 (UNICEF, 2020). No Brasil, o número de migrantes e refugiadas em 2019 atingiu 804 mil pessoas, sendo cerca de 113 mil crianças (UNICEF, 2020).

Ante esse contexto, é fundamental a elaboração de ações promotoras do desenvolvimento voltadas às especificidades da infância, considerando os impactos do deslocamento forçado nesse período da vida. Sob tal direção, a partir da ação extensionista Pequenos do Mundo, da Universidade Federal do Paraná (UFPR), temos como objetivo discutir aqui a metodologia desenvolvida, nos valendo da arte em suas diferentes expressões e manifestações, para o resgate e compartilhamento das memórias afetivas das crianças e de suas famílias sobre cultura de origem, trajetórias e vivências. Para tanto, apresentaremos o Pequenos do Mundo; na sequência, discorreremos sobre os pressupostos teóricos metodológicos da Psicologia Histórico-Cultural que fundamentam as ações 
desenvolvidas; então apresentaremos a metodologia elaborada; e, após, discutiremos os desdobramentos das ações desenvolvidas.

\section{PEQUENOS DO MUNDO}

O projeto Pequenos do Mundo ${ }^{1}$ foi elaborado com o intuito de realizar o acolhimento e ações específicas com crianças migrantes. A necessidade dessas ações surgiu devido à demanda do projeto Português Brasileiro para Migração Humanitária (PBMIH), que realiza desde 2013 diversas ações de acolhimento com a comunidade migrante, entre elas aulas gratuitas de português brasileiro na cidade de Curitiba. Foi possível observar ao longo do trabalho realizado pelo PBMIH que muitas famílias, principalmente as mulheres, não frequentavam as aulas regularmente por não terem com quem deixar suas crianças ou, então, as levavam para acompanhar as aulas de português. Em vista disso, foi necessária a organização de um espaço seguro destinado a essas crianças.

No início de 2017, por iniciativa de integrantes do PBMIH, foi criada a "sala das crianças" com o objetivo de acolhê-las. Ao longo dos encontros, que ocorriam aos sábados $^{2}$, novas demandas foram surgindo, o número de crianças aumentando e o projeto se reformulando através do trabalho conjunto entre Psicologia e Letras. Deste modo, o Pequenos do Mundo surge como um projeto interdisciplinar cujo objetivo é proporcionar um espaço no qual a arte, a brincadeira e o lúdico sejam promotores do desenvolvimento, e para tanto, buscamos realizar a partir dos pressupostos da Psicologia Histórico-Cultural atividades sistematizadas e variadas que visam a potencialização do desenvolvimento das crianças. Neste contexto, para que fosse possível a realização de tais atividades, foi essencial a organização de um espaço adequado, bem como o planejamento das ações.

\footnotetext{
${ }^{1}$ O Pequenos do Mundo é uma das frentes de trabalho do projeto de extensão universitária Migração e Processos de Subjetivação: Psicologia, Psicanálise e Política na rede de atendimento aos migrantes e do projeto de extensão Português Brasileiro para Migração Humanitária (PBMIH) da UFPR. Vale destacar que tais projetos de Psicologia e de Letras, respectivamente, compõem o Programa de extensão Política Migratória e Universidade Brasileira (PMUB) da UFPR, signatário da Cátedra Sérgio Vieira de Mello da ACNUR. Juntamente com os projetos Migrações, Refúgio e Hospitalidade, do curso de Direito; Capacitação em Informática para Migração Humanitária, da área de Computação; Observatório das Migrações, das Ciências Sociais; e o Caminhos do SUS, de Medicina. O PMUB estabelece ainda parcerias para o desenvolvimento de ações conjuntas com o curso de História, através do PET-História, e com o curso de Comunicação Social, com o programa de extensão Núcleo de Comunicação e Educação Popular.

${ }^{2}$ Os encontros com a comunidade migrante, crianças e suas famílias, são realizados todo sábado letivo, no período da tarde, das $15 \mathrm{~h} 00$ às $18 \mathrm{~h} 00$, paralelamente às aulas de português oferecidas pelo PBMIH; desse modo, cada encontro tem duração média de $3 \mathrm{~h}$.
}

Revista X, v. 16, n. 2, p. 485-524, 2021. 
Entre 2017 e 2019, participaram do projeto cerca de 93 crianças de diferentes países: Venezuela, Haiti, Colômbia, Síria, Egito, Nigéria, Irã, Peru, Iêmen, Líbano, Líbia, Bolívia, República Democrática do Congo e Benin ${ }^{3}$. Ademais, vale destacar que a metodologia de porta giratória ${ }^{4}$ das aulas de português permite a inscrição de novos alunos toda semana, e devido a essa característica o número de crianças oscila semanalmente, com idades que variam de 1 a 15 anos.

Em 2019, participaram do projeto 61 crianças vindas de 11 países diferentes. O país de origem mais frequente entre as famílias foi a Venezuela, com 30 crianças; a segunda nacionalidade mais frequente foi a haitiana, com 10 crianças, seguida pela egípcia, colombiana e iraniana, com cinco, quatro e três crianças, respectivamente. Síria, Iêmen, Nigéria, Líbano, Líbia e Bolívia são as nacionalidades com menor número. Vale notar que o perfil das crianças participantes do projeto é um reflexo dos diferentes fluxos migratórios internacionais, os quais possuem características específicas. No seu início, em 2017, a maior parte das crianças participantes eram haitianas, reflexo do intenso fluxo migratório do Haiti para o Brasil ${ }^{5}$.

Entre 2015 e 2016, houve um grande contingente de pessoas sírias vindo para o Brasil devido aos conflitos no Oriente Médio. Até 2018, segundo dados do Comitê Nacional para os Refugiados (CONARE, 2019), o Brasil reconheceu 11.231 pessoas

\footnotetext{
${ }^{3}$ Os países estão listados por ordem de predominância de nacionalidades.

${ }^{4}$ Uma vez que a população atendida é constituída por migrantes em deslocamento forçado (diferente de alunos intercambistas que podem planejar e organizar sua viagem, migrantes na condição de refúgio chegam a todo momento ao país, pois seu deslocamento é emergencial), o formato tradicional de um curso de língua não atenderia essa especificidade. À vista disso, o PBMIH desenvolveu uma metodologia intitulada "porta-giratória" que consiste basicamente em uma aula que abre e fecha nela mesma e prevê a entrada e/ou a saída de um aluno em qualquer momento (cf. CURSINO, ALBUQUERQUE, FIGUEIREDO SILVA, GABRIEL e ANUNCIAÇÃO, 2016). ${ }^{5}$ Este fluxo migratório apresentou uma característica muito própria e distinta de outras migrações. A migração haitiana para o Brasil teve como ponto de partida o terremoto de 2010. Por esse motivo, na interpretação governamental, pessoas haitianas não se enquadram nos critérios necessários para a concessão do visto de refugiado, pois trata-se, para as autoridades brasileiras, de uma questão de acolhimento por questões humanitárias. Até os dias atuais, os vistos humanitários para as pessoas haitianas continuam baseando-se nas dificuldades de reconstrução do país em função do terremoto como causa da emigração haitiana para o Brasil (BAENINGER; PERES, 2017). Existem poucos dados sobre a migração haitiana devido ao fato de não serem contabilizados em pesquisas da ACNUR, por exemplo, uma vez que não se enquadram na categoria de refúgio.
}

Revista X, v. 16, n. 2, p. 485-524, 2021. 
refugiadas, das quais a nacionalidade predominante era a Síria $(51 \%)^{6}$. Já a partir de 2018, houve um grande fluxo de pessoas venezuelanas vindo ao Brasil, como aponta o mesmo estudo; neste ano, das 80.057 solicitações de reconhecimento da condição de refugiado que o Brasil recebeu, 61.681 eram venezuelanas. A partir disso, a diversidade de nacionalidades das crianças que frequentam o projeto tornou-se mais clara, como expõe o gráfico abaixo.

Figura 1: Nacionalidade das crianças que frequentaram o projeto em 2019

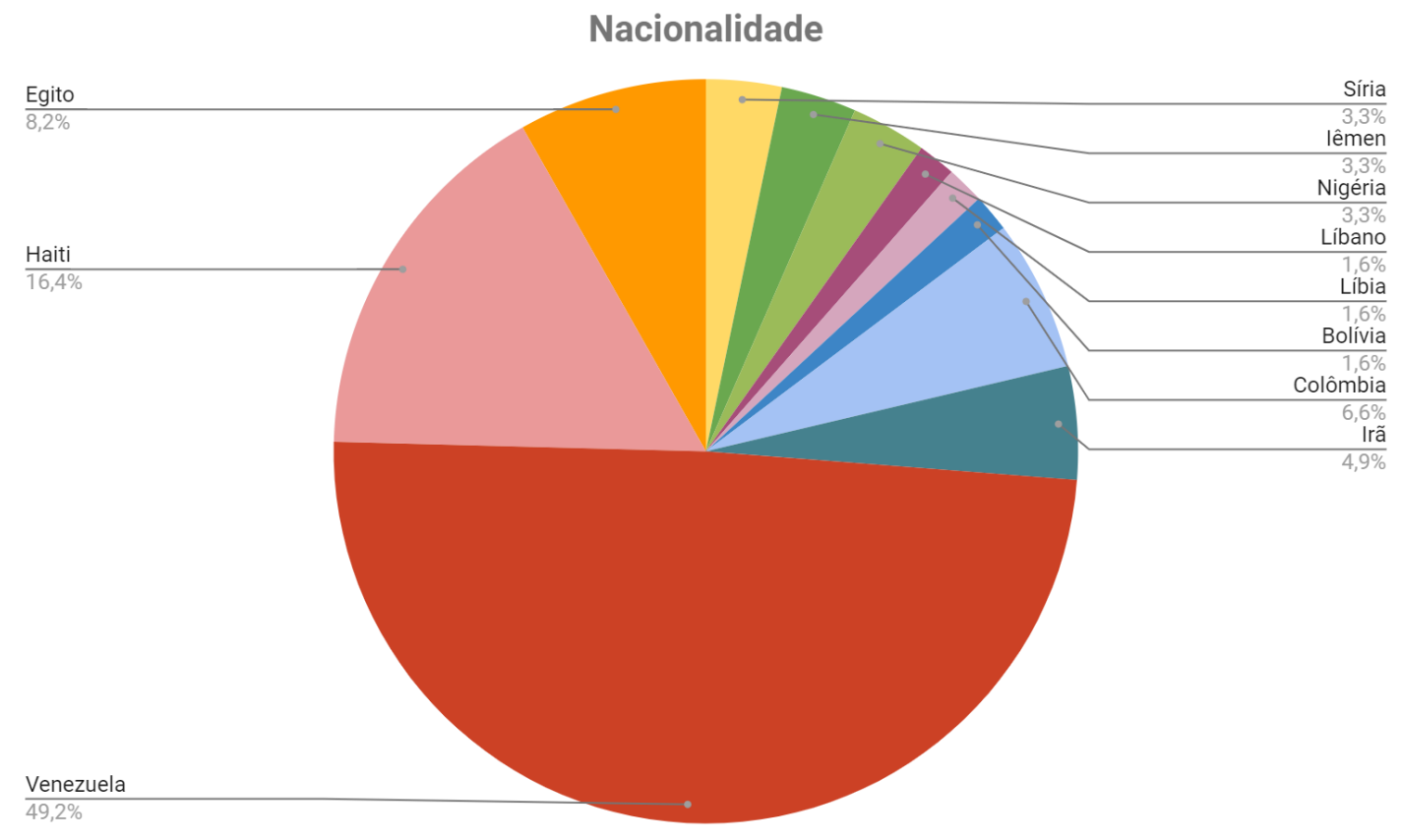

Fonte: As Autoras (2020).

\footnotetext{
${ }^{6}$ Faz-se importante fazer uma distinção entre as definições de migração e refúgio. A migração é caracterizada por um movimento de pessoas, de duração variada, com repercussões psicológicas, sociais, políticas e culturais para o sujeito e seu contexto. As migrações podem ser voluntárias, quando a mudança decorre de uma decisão individual ou coletiva, na qual há, geralmente, um planejamento da partida e da chegada no novo lugar, ou involuntárias, quando o deslocamento é imposto por motivos de perseguições religiosas, políticas e/ou ideológicas, graves violações de direitos humanos, efeitos de catástrofes naturais, entre outros. A condição de refúgio é um exemplo de migração involuntária. A pessoa refugiada é aquela que em razão de fundados temores de perseguição devido à sua raça, religião, nacionalidade, associação a determinado grupo social ou opinião política, encontra-se fora de seu país de origem e que, por causa dos ditos temores, não pode ou não quer regressar ao mesmo (MARTINS-BORGES; JIBRIN; BARROS, 2015; ACNUR, 2004). 
\#PraCegoVer: Gráfico em forma de círculo. Cada nacionalidade é representada por uma cor e uma fatia. No sentido horário partindo das 12 horas temos: amarelo 3,3\% Síria, verde escuro 3,3\% Iêmen, verde claro 3,3\% Nigéria, roxo 1,6\% Líbano, rosa 1,6\% Líbia, azul 1,6\% Bolívia, azul claro 6,6\% Colômbia, verde musgo 4,9\% Irã, vermelho 49,2\% Venezuela, rosa $16,4 \%$ Haiti e laranja $8,2 \%$ Egito.

A sistematização de informações das crianças é feita por meio de relatórios semanais, relatórios individuais e fichas de informações pessoais. No entanto, existem fatores que implicam na imprecisão de dados sobre algumas crianças, pois devido à oscilação da frequência ao longo dos encontros, há casos em que as crianças participaram poucas vezes ou foram a somente um encontro. Além disso, as pessoas responsáveis pelas crianças têm a liberdade de não aceitar compartilhar dados específicos, como a idade. Considerando isso, os registros apontam para um predomínio da faixa etária entre quatro e seis anos.

Figura 2: Faixa etária das crianças que frequentaram o Pequenos do Mundo em 2019.

\section{Faixa etária}

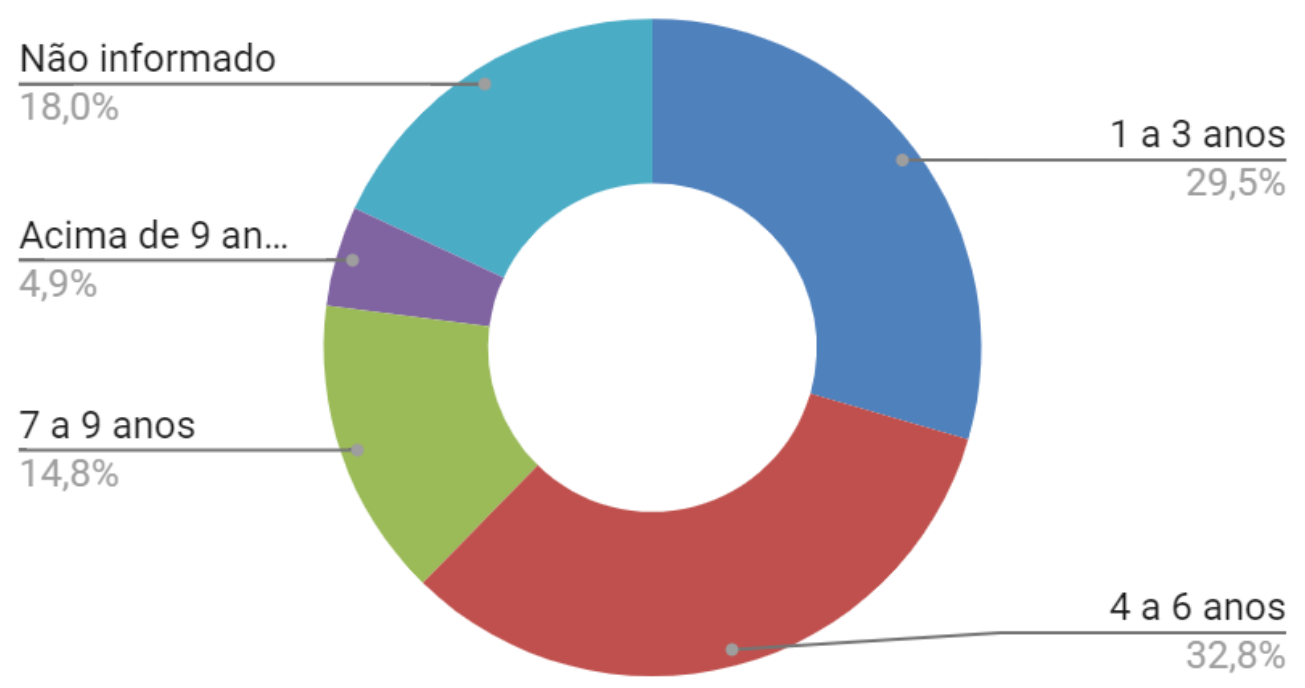

Fonte: As Autoras (2020).

\#PraCegoVer: Gráfico em forma de círculo. Cada faixa etária está representada por uma cor e uma fatia. No sentido horário partindo das 12 horas temos azul escuro 29,5\% 1 a 3 anos, vermelho $32,8 \% 4$ a 6 anos, verde $14,8 \% 7$ a 9 anos, roxo $4,9 \%$ acima de 9 anos, azul claro $18 \%$ não informado.

O projeto é composto por uma equipe interdisciplinar, da qual atualmente participam docentes, discentes e profissionais de Psicologia, Letras e Artes Cênicas, 
totalizando 13 integrantes. A interdisciplinaridade é um fator vital para o nosso trabalho, pois cada área de conhecimento traz contribuições diferentes que convergem para a potencialização do desenvolvimento das crianças através das atividades planejadas.

Por meio das supervisões semanais e do planejamento conjunto das atividades, percebemos a necessidade da organização metodológica do projeto. Esse processo de reestruturação envolveu desde a criação do nome "Pequenos do Mundo" até a complexificação e o aperfeiçoamento das atividades, bem como o desdobramento da turma das crianças em dois grupos divididos de acordo com o período do desenvolvimento infantil. A organização da rotina de trabalho junto com as crianças, com momentos fixados como a "contação de história", foi fundamental para a potencialização das atividades e para a coesão do grupo. Junto a essa organização, novas necessidades próprias das demandas das famílias migrantes e refugiadas surgiram e ações específicas foram elaboradas.

Isto posto, as atividades desenvolvidas seguem um tema central guiado por ações específicas. Estas requerem uma estruturação e planejamento prévio, que ocorre por meio de supervisões semanais, organização de uma escala de presença nos encontros, registro e sistematização das atividades. Assim, desenvolvemos e acompanhamos a progressão das atividades, nos atendo às particularidades de cada criança. $\mathrm{O}$ olhar voltado para as singularidades das crianças mostrou-se essencial para o trabalho potencializador com os pequenos migrantes, e parte deste olhar envolve o resgate e a valorização das memórias afetivas. Para tanto, os fundamentos da Psicologia Histórico-Cultural foram basilares para o desenvolvimento das atividades, os quais serão descritos no tópico seguinte.

\section{INFÂNCIA, MIGRAÇÃO, ARTE E MEMÓRIA: DISCUSSÕES A PARTIR DA PSICOLOGIA HISTÓRICO-CULTURAL}

Como já apresentado, o número de migrantes mundiais tem crescido consideravelmente nos últimos anos, o que faz crescer também a quantidade de crianças em deslocamento. Apesar disso, as implicações dos movimentos migratórios na infância não têm sido amplamente abordadas nos estudos sobre o tema (DEMARTINI, 2011).

Para melhor compreender os impactos da migração na infância, é necessário elucidar alguns dos pressupostos teóricos que dizem respeito ao desenvolvimento infantil. Para a Psicologia Histórico-Cultural, o desenvolvimento infantil não acontece espontaneamente: apesar de ter como substrato aspectos biológicos, esse processo é determinado pelas condições concretas de vida da criança e pelas mediações que lhe são oportunizadas. É caracterizado, então, pelas unidades entre o material e o psíquico e entre o social e o pessoal (VIGOTSKI, 1996). Assim, o desenvolvimento acontece sempre na 
relação com o social e se expressa pela formação de novas capacidades e motivações em diversos momentos na vida da criança. Em cada período, isso configura novas relações: da criança com o mundo e com si mesma e, de maneira recíproca, do mundo para com ela. Essa relação única e irrepetível que se estabelece é denominada de situação social do desenvolvimento e é ela que será a base para todas as transformações significativas na personalidade da criança (VIGOTSKI, 1996).

O elemento conector dessa relação entre a criança e o mundo, e o que explica as diferenças qualitativas entre as idades, é a atividade-guia ou atividade dominante. É essa atividade que mobiliza as transformações mais significativas no psiquismo infantil, que direciona mudanças psicológicas na personalidade, bem como orienta todas as outras atividades da criança (LEONTIEV, 1988). Dessa forma, a transição entre um período do desenvolvimento e outro é provocada pela mudança de atividade-guia ou dominante, na qual a atividade que antes era central ainda permanece na vida da criança, mas deixa de ser aquela com função orientadora e mobilizadora das demais. A mudança na atividade não ocorre pelos marcos etários ou indícios externos do comportamento, mas pela “[...] contradição explícita entre o modo de vida da criança e suas potencialidades, as quais já superaram este modo de vida. De acordo com isso, sua atividade é reorganizada e ela passa, assim, a um novo estágio do desenvolvimento de sua vida psíquica" (LEONTIEV, 1988, p. 66). A depender das condições concretas de vida, são mobilizadas novas necessidades, interesses e capacidades correspondentes às suas potencialidades em mudança, reorganizando a forma de atuar, agir e pensar o mundo (LEONTIEV, 1988).

A Psicologia Histórico-Cultural propõe uma periodização que contempla épocas e períodos (RIOS; ROSSLER, 2017). As épocas são a primeira infância, a infância e a adolescência, e em cada uma delas se intercalam um momento de prevalência da esfera motivacional, que é a relação da criança com outras pessoas, e um outro no qual prevalece a esfera técnico-operacional, isto é, a relação da criança com o uso social dos objetos (PASQUALINI; EIDT, 2016). Os períodos são nominados de acordo com a atividade-guia ou dominante, sendo elas: a comunicação emocional direta, atividade objetal manipulatória, jogos de papéis, atividade de estudo, comunicação íntima pessoal e atividade profissional de estudos ${ }^{7}$. As transições entre períodos são idades críticas porque envolvem mudanças estruturais na consciência infantil, marcadas por rupturas bruscas

\footnotetext{
${ }^{7}$ Para aprofundamento dos diferentes períodos do desenvolvimento psíquico, sugerimos o livro "Periodização do desenvolvimento psíquico: do nascimento à velhice", organizado por Lígia Márcia Martins, Angelo Antonio Abrantes e Marilda Gonçalves Dias Facci, publicado pela Editora Autores Associados.
} 
em função da perda dos interesses que orientavam a atividade da criança e para os quais direcionava seu tempo e atenção (VIGOTSKI, 1996).

Nesse contexto, ao discutirmos a migração na infância, é preciso considerar que a migração tem impactos singulares em cada criança, determinados pelas condições objetivas em que se deu o deslocamento e, também pelo momento da vida em que aconteceu, já que cada período é qualitativamente diferente do outro. Como discute Vigotski (2018a, p. 81), "Um mesmo acontecimento ocorrido em idades diferentes da criança, ao se refletir na consciência de modo absolutamente diferente, tem para ela um significado absolutamente diferente". Sob tais pressupostos, compreendemos que o deslocamento tem repercussões únicas em todo o sistema funcional dos processos psicológicos para cada criança inserida em um contexto particular. Nesse sentido, um acontecimento que impacta o cotidiano da criança e é mobilizador de sentimentos e reflexões ganha destaque em sua vida a depender das condições nas quais ocorreu e da relação estabelecida entre ela e o mundo naquele momento. Ainda segundo Vigotski (2018a, p. 75), “[...] não é esse ou aquele momento, tomado independentemente da criança, que pode determinar sua influência no desenvolvimento posterior, mas o momento refratado através da vivência da criança". Vigotski (2018a) explica que a vivência é uma unidade indivisível entre as especificidades da personalidade e do meio, posto que se vivencia algo que está fora da pessoa, mas que ocorre de forma particular. No entanto, para além das particularidades constitutivas, é preciso saber “[...] quais delas, em dada situação, desempenharam papel decisivo na definição da relação da criança com determinada situação, enquanto em uma situação distinta, outras o fizeram" (VIGOTSKI, 2018a, p. 78).

Sob tais condições, é fundamental apreender a relação da criança com o meio, a vivência da criança, o modo como atribui sentido e se relaciona afetivamente com certo acontecimento (VIGOTSKI, 2018a). A partir disso, fica clara a compreensão de que não é possível a separação entre o que é de caráter mental e o que é de caráter emocional; entre as esferas cognitiva e afetiva. Se temos como pressuposto que a criança se desenvolve a partir da relação que ela estabelece com o seu entorno e que esse processo depende da compreensão que ela tem sobre os acontecimentos de sua vida (e não somente dos acontecimentos de fato), não podemos excluir o papel das emoções. Como explicam Martins e Carvalho (2016),

A unidade afetivo-cognitiva que sustenta a atividade humana demanda a afirmação da emoção como dado inerente ao ato cognitivo e viceversa, já que nenhuma emoção ou sentimento, bem como nenhum ato 
de pensamento, podem se expressar como conteúdos puros, isentos um do outro. (p. 702)

A unidade afetivo-cognitiva é essencial para o desenvolvimento de todas as funções psicológicas, que são: a memória, a atenção, a percepção, a sensação, o pensamento, a linguagem, a imaginação, as emoções e os sentimentos ${ }^{8}$. No caso da primeira, que é tema central das atividades apresentadas aqui neste estudo, o conteúdo das lembranças da criança tem relação intrínseca com o que lhe afetou. Ou seja, a criança se recorda daqueles acontecimentos com os quais ela criou mais vínculos afetivos, sejam eles positivos ou negativos. Aqui, não temos a intenção de aprofundar o debate sobre o desenvolvimento da memória em toda a sua complexidade, mas a compreensão da indissociabilidade entre as experiências afetivas e o conteúdo recordado pela criança, que nos permitem um novo olhar para o trabalho com crianças migrantes no que diz respeito às memórias afetivas.

Em termos gerais, Luria (1994) descreve que o desenvolvimento da memória na idade infantil é pautado por mudanças e transformações profundas, ou saltos qualitativos, significando que não podemos considerá-lo como um processo linear ou crescente. No entanto, o autor destaca que a capacidade de registrar e fixar vestígios seria maior nos períodos pré-escolares do que em qualquer outro momento da vida. Porém, existe uma contradição nesta ampla capacidade mnemônica da criança nestes períodos (até a idade escolar): "é difícil organizá-la, torná-la seletiva, ela ainda não é em nenhuma medida uma memória arbitrária capaz de memorizar o necessário, orientado para um dado fim, separando os vestígios fixáveis dentre todos os outros" (LURIA, 1994, p. 92). Essa habilidade de organização começa a se fazer presente a partir da entrada na escola, em que os conteúdos, assim como as funções psicológicas, passam a ser organizados e direcionados. Para Luria (1994), o maior salto de desenvolvimento da memória na idade

\footnotetext{
${ }^{8}$ A esse respeito, é importante pontuarmos, em consonância com Martins e Carvalho (2016, p. 701), que Vigotski “"...] postulou a distinção entre propriedades psíquicas, naturalmente instituídas, - denominando-as funções psíquicas elementares - e propriedades culturalmente formadas, denominadas de funções psíquicas superiores. Por essa via, identificou o desenvolvimento psicológico com o movimento engendrado por contradições internas entre os legados natural e cultural, em que as funções psíquicas se transformam e oportunizam o autocontrole da conduta, requerido aos domínios do sujeito sobre o objeto. Na qualidade de produtos do desenvolvimento social da humanidade, as funções psíquicas superiores instituem-se como formas supraorgânicas de conduta, resultantes do uso de signos e do emprego de ferramentas, graças aos quais os comportamentos se tornam conscientemente planejados e controlados". Reiteramos que tais funções não se desenvolvem de modo independente umas das outras, mas se articulam em um sistema psicológico, interfuncional.
}

Revista X, v. 16, n. 2, p. 485-524, 2021. 
escolar se encontra na condição de "utilizar meios auxiliares externos para o processo de memorização" (p. 94), o que se torna automático nas idades posteriores e na vida adulta. Mas, como todos os processos do desenvolvimento infantil, essas condições só são criadas a partir do que é mobilizado na vida dessa criança, se a memória tem bases para formar tais conexões externas e se desenvolver de fato.

Por isso, consideramos de suma importância possibilitar esse desenvolvimento da memória com todas as idades, nos complexos nexos estabelecidos entre o sistema psicológico. Isso posto, faz-se importante discutir o motivo desse foco nas memórias afetivas e a razão pela qual utilizamos a arte como recurso neste trabalho. Assim como já apontado, acreditamos que a práxis da Psicologia, e sobretudo da Psicologia HistóricoCultural, precisa ter como objetivo a emancipação dos indivíduos para que eles próprios possam atuar de forma crítica e transformadora sobre as suas realidades. Por sua vez, a partir de Martin-Baró (1997) compreendemos que a emancipação dos indivíduos só acontece por via da conscientização das condições objetivas de vida, principalmente daquelas opressoras ou limitantes, oriundas das formas de organização social vigentes. $O$ autor destaca como fator fundamental para esse processo o resgate da memória histórica, tanto individual quanto coletiva; em suas palavras: "tudo isso lhe permite não só descobrir as raízes do que é, mas também o horizonte do que pode chegar a ser. Assim, a recuperação de sua memória histórica oferece a base para uma determinação mais autônoma do seu futuro" (MARTIN-BARÓ, 1997, p. 16).

Dessa forma, trabalhar as memórias afetivas com crianças migrantes tem como objetivo situá-las e protagonizá-las em suas histórias de vida para que elas possam compreender de forma mais consciente os seus processos migratórios, especialmente neste momento de construção de suas identidades pessoais e culturais. Como discute Braga (2000), neste processo de resgate das memórias afetivas "os fatos passados matizam-se, o sujeito se dobra sobre a própria vida. Somos levados a pensar em como, pela narração de nossas lembranças, vamos nos tornando sujeitos e nos inscrevendo na história. Lembrar é narrar. Narrar é lembrar" (p. 84).

Porém, o ato de narrar as memórias não é restrito à língua falada ou escrita. Produções materiais, visuais e simbólicas são recursos valiosos para a expressão da criança, as quais envolvem um processo de criação. A atividade criadora é aquela na qual se cria algo novo a partir de (re)combinações dos elementos da realidade (VIGOTSKI, 2018b). Esta atividade está presente em todos os aspectos da cultura humana uma vez que é ela que "[...] faz do homem um ser que se volta para o futuro, erigindo-o e modificando o seu presente" (VIGOTSKI, 2018b, p. 16). O autor (2018b) destaca que a atividade 
criadora é dependente da diversidade das experiências da criança já que esta é a base para o desenvolvimento da imaginação. Nas palavras de Vigotski (2018b, p. 89), "[...] a criação infantil alimenta-se de impressões que partem da realidade, reelaborando essas impressões e levando as crianças a um entendimento e um sentimento mais profundo dessa realidade".

Rodrigues et al (2016) enfatizam que o processo de criação e expressão artística promove a formação da criança, bem como a humanização dos sentidos. Para tanto, é fundamental propiciar condições para a criança imaginar e expressar suas ideias, expandir as referências artísticas e culturais, bem como exercer o ato criativo (RODRIGUES et al, 2016). Desta forma,

\begin{abstract}
Através da imaginação criadora, do fazer artístico, a criança é capaz de desconstruir e reelaborar suas hipóteses, transformando objetos, matérias e materiais oferecidos pela cultura e pela natureza, em algo significativo, sendo esse um momento importante a considerar em seu processo criador, garantindo assim, a experiência e a ampliação do conhecimento estético (RODRIGUES et al, 2016, p. 466).
\end{abstract}

Destacamos, sob os fundamentos da Psicologia Histórico-Cultural, que a arte, em suas diferentes expressões e manifestações, pode promover a ampliação da compreensão de mundo e de si. Isso porque, conforme apontam Nascimento e Pasqualini (2016), a arte não se reduz a expressar uma ideia ou sentimento, mas tem a potência de instigar novas possibilidades de sentir e de compreender a vida. Neste sentido, ao expor as contradições da realidade humana, representando-a em seus aspectos essenciais, a arte possui papel formativo ao mobilizar aspectos cognitivos e afetivos, humanizar os sentidos, complexificar a sensibilidade e ressignificar as experiências e vivências (ABRANTES, 2016). Assim, é fundamental que a criança tenha acesso e relação ativa com as diferentes expressões artísticas - literatura, poesia, música, artes visuais, etc - no sentido de promover sua sensibilidade estética e potencializar sua capacidade criadora (NASCIMENTO; PASQUALINI, 2016).

Como pontua Vigotski (2018b), “[...] a criação, na verdade, não existe apenas quando se criam grandes obras históricas, mas por toda parte em que o homem imagina, combina, modifica e cria algo novo, mesmo que esse novo se pareça um grãozinho, se comparado às criações dos gênios" (p. 17). Ao desenharem, por exemplo, as crianças não têm a mesma pretensão que tem as algumas pessoas adultas de criarem grandes obras de arte, mas sim a de expressar suas vivências, sendo o processo criativo mais importante do 
que a obra final. Imbuídas desses pressupostos, desenvolvemos uma metodologia para as ações com os Pequenos do Mundo.

\section{ELABORAÇÃO DE METODOLOGIA ESPECÍFICA PARA AÇÕES COM CRIANÇAS MIGRANTES}

\section{Pressupostos metodológicos}

Como já mencionado, este trabalho pretende refletir sobre as atividades desenvolvidas no Pequenos do Mundo, o qual é construído a partir dos pressupostos da Psicologia Histórico-Cultural, norteada pelo método do materialismo histórico-dialético. Entendemos pela epistemologia adotada que as ações construídas possuem propósito, sentido e finalidade, sendo, portanto, elaboradas com o objetivo de potencializar o desenvolvimento infantil. O Pequenos do Mundo proporciona à criança um espaço de trocas e de possibilidades de expressão das vivências da infância e da sua relação com a migração, tendo a arte papel fundamental nesse processo.

Ademais, as ações do Pequenos do Mundo se alinham aos pilares da universidade pública brasileira de ensino, pesquisa e extensão. Cumpre-se, em sua totalidade, o estabelecimento de pontes entre o campo acadêmico e a comunidade. Desenvolver essa tríade é um processo interdisciplinar, educativo e político, que promove uma interação transformadora para a comunidade e para a universidade. Nesse sentido, nossas atividades visam um desenvolvimento dialógico e dinâmico centrado na escuta ativa ${ }^{9}$ da comunidade e no conhecimento técnico de diferentes áreas (Psicologia, Artes Cênicas e Letras) para auxiliar na construção dos saberes, dos processos e das ações.

A primeira etapa para elaboração de uma ação (macro e micro ${ }^{10}$ ) é a identificação de uma demanda que emerge da comunidade. Uma vez identificada a demanda, iniciamos o processo de elaboração da proposta; em seguida, retomamos a mediação

\footnotetext{
${ }^{9}$ Convém definirmos o uso do termo escuta ativa que adotamos neste texto. Aqui, o termo escuta ativa versa sobre estabelecer um canal de comunicação aberto, eficiente, dinâmico e ativo, que atue como uma ferramenta de (re)construção no mundo; visto que o Pequenos do Mundo é uma ação extensionista da UFPR, tendo assim como pilar a Interação dialógica com a sociedade visando uma troca de saberes e possibilitando um conhecimento novo que contribua para o enfrentamento da desigualdade e da exclusão social Para uma discussão mais aprofundada acerca dos cinco pilares da extensão universitária na UFPR, ver RESOLUÇÃO $\mathrm{N}^{\circ}$ 72/11-CEPE, disponível em: http://www.soc.ufpr.br/portal/wp-content/uploads/2016/07/resolucao_cepe_01122011-622.pdf.

${ }^{10}$ As ações macro são assim denominadas por terem um caráter mais permanente, ou seja, são utilizadas em atividades ao longo de todo o ano ou semestre letivo. Estas ações são alimentadas pelas micro, atividades pontuais que se encerram em um encontro e complementam as ações macro. Revista X, v. 16, n. 2, p. 485-524, 2021. 
com a comunidade acerca da proposta elaborada. Depois, caso seja necessário, refinamos a proposta e seguimos para o planejamento/estruturação das ações; após a etapa de planejamento, aplicamos as atividades. Ao final de cada aplicação reavaliamos o processo e obtemos ressignificações e materializações, ou seja, produtos simbólicos e/ou materiais resultantes de cada atividade. É mister ressaltar que a escuta ativa e o diálogo constante com a comunidade transpassam todo o processo de elaboração da ação, resultando em constantes retornos e reformulações de todas as fases da proposta. A Figura 3 ilustra o processo de desenvolvimento das ações propostas pelo Pequenos do Mundo.

Figura 3: Ações do Pequenos do Mundo.

\section{Ações - Pequenos do Mundo}

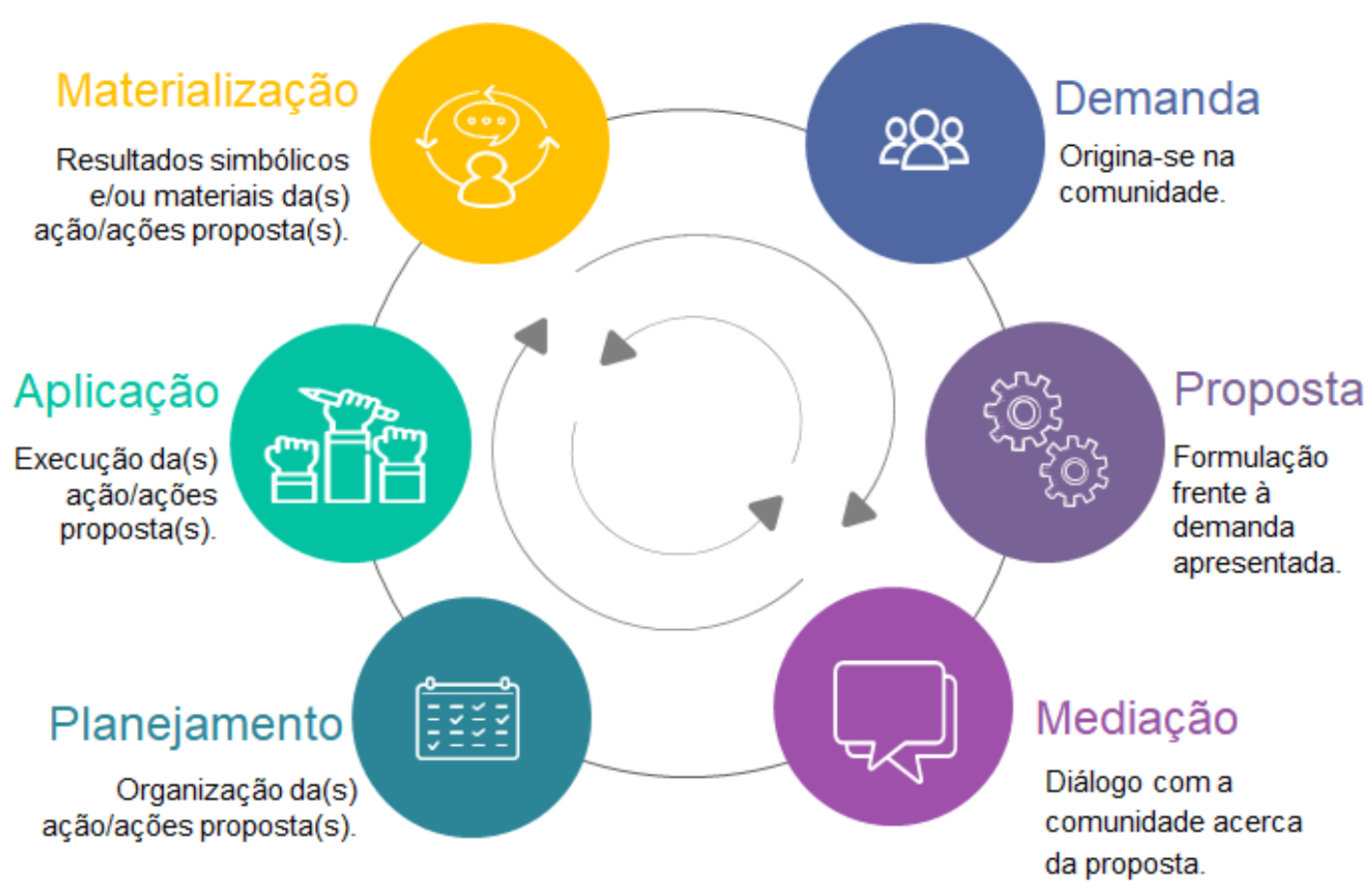

Fonte: As Autoras (2020).

\#PraCegoVer: Esquema em formato circular composto por seis círculos menores coloridos com ícones no centro e explicações ao lado. Título Ações Pequenos no Mundo. No sentido horário, às 13 horas, círculo azul, ícone de três pessoas - Demanda: origina-se na comunidade. Às 15 horas, círculo roxo, ícone de duas engrenagens - Proposta: formulação frente à demanda apresentada. Às 17 horas, círculo lilás, ícone de dois balões de fala - Mediação: diálogo com a comunidade acerca da proposta. Às 19 horas, círculo verde escuro, ícone de um calendário - Planejamento: organização das ações propostas. Às 21 horas, círculo verde claro, ícone de três mãos, uma delas segurando um lápis - Aplicação: execução das ações propostas. Às 23 horas, círculo amarelo ícone de uma pessoa com um balão de fala Materialização: resultados simbólicos e/ou materiais das ações propostas. 
Em 2019, materializamos a proposta "Contando Histórias, Resgatando Memórias", que visa um resgate histórico-cultural dos percursos, histórias, vivências e narrativas das crianças e de suas famílias. Na sequência nos dedicaremos aos detalhamentos dessa proposta planejada e desenvolvida durante o ano letivo de 2019, constituída por ações macro e ações micro. A seguir, descreveremos o planejamento da proposta de trabalho desenvolvida durante o ano letivo de 2019 e, posteriormente, exemplificaremos os processos envolvidos na aplicação de uma ação micro e uma ação macro.

\section{Contando histórias, Resgatando memórias}

Na vivência com a comunidade, observamos uma movimentação direcionada ao apagamento de costumes, ritos, língua materna etc; tal processo, possivelmente, é motivado pela necessidade urgente de adaptar-se ao novo país. A pessoa migrante adota novos costumes sociais e abre mão de aspectos próprios de sua cultura de origem a fim de se inserir socialmente, e viver esta nova realidade traz consigo um símbolo de perda e de transformação social, e ainda conduz a uma reconstrução identitária. Conforme ressalta Campano (2007), a criação de espaços seguros é de suma importância para a recuperação cultural e compartilhamento de suas histórias e lembranças.

Portanto, foi importante construir uma metodologia que buscasse o resgate de aspectos do país (e região) materno e da história das crianças e de seus familiares, destacando questões pertinentes à infância. A partir desse objetivo, elaboramos uma proposta que promoveu a participação e o envolvimento das famílias para resgatar as memórias afetivas através de:

1) Atividades conjuntas entre familiares e crianças e atividades específicas com familiares;

2) Sistematização de ações que contemplem crianças de diferentes idades e culturas; e

3) O uso da literatura infantil como fio condutor de atividades dirigidas a fim de estimular a discussão de temas previamente elaborados.

Debruçamo-nos então no desenvolvimento da proposta Contando histórias, resgatando memórias, a qual objetivou ao longo de 2019 a construção de duas produções materiais, o Livro de Memórias ${ }^{11}$ e a Caixa de Memórias - ações macro fomentadas por

${ }^{11}$ O livro "Minhas Memórias" é um compilado das atividades realizadas pela criança durante o ano. Cada livro é único e específico de cada criança, posto que contém a descrição e foto das ações realizadas a cada dia, seguida das produções da criança (ou foto delas) e o relato da equipe sobre como foi o dia da criança. O livro foi organizado da seguinte maneira: 1. Apresentação do projeto; 2. Agradecimentos; 3. Dedicatória para as crianças; 4 . O perfil da criança; 5 . Atividades. 
ações micro - as quais possibilitaram às crianças e às famílias se (re)conectarem com as suas vivências, percursos, narrativas e culturas. Ademais, as ações possibilitaram a elaboração simbólica e material sobre processos culturais e identitários desde a infância: a criança pode tomar posse para si uma ferramenta que promove o resgate e o compartilhamento de aspectos da sua relação com seus pares e com o meio.

Elaboramos, portanto, dois eixos de ação: o primeiro, Quem sou eu?, em que abordamos temas sobre identificação, rotina, casa, escola, com quem mora e o que gosta e não gosta de fazer, resgatando aspectos identitários da criança. No segundo eixo, o Memórias afetivas, trabalhamos os cenários geográficos, alimentação, histórias, costumes, cantigas e brincadeiras do país de origem, com o objetivo do resgate da identidade cultural. A intencionalidade dos eixos das ações se deu ao retomar aspectos importantes para a criança e a sua família, sobre a cultura materna das crianças, a sua história familiar, bem como sua rotina, vida no Brasil, como eram no país em que nasceram e como estavam sendo aqui.

Além disso, pretendemos pôr em prática intervenções específicas, direcionadas e intencionais para a mobilização de potencialidades para vivenciar a infância em meio a mudanças iminentes da cultura, dos costumes e da língua. Sobre a mediação realizada durante a construção do livro, nos coube o processo de valorização e construção do registro de histórias de vida, sempre respeitando o ritmo, as necessidades e os desejos da criança e da família.

Ao longo do processo, o contato com a diversidade de conteúdos e componentes podiam gerar dúvidas por parte da criança na criação da sua própria história. Nesses momentos, era preciso que estivéssemos atentas para criar meios que orientassem as crianças na busca de respostas sobre a própria história. Além disso, respeitamos casos em que a criança e/ou a família não quisesse compartilhar a fundo determinado conteúdo.

Com esse cenário exposto, partimos do pressuposto de que produções artísticas, em geral, e a literatura infantil em específico - com seus personagens, enredos, cores, sonorizações -, possibilitam à criança elaborar reflexões e impressões, estabelecer relações, sensibilizar-se com a outra, pensar em conflitos e dramas da vida para além da sua vivência imediata, ampliando as fronteiras da sua realidade e possibilitando o novo (CHAVES, 2009). Assim, a partir da contação de histórias foram resgatadas memórias e vivências das crianças e de suas famílias. A figura 4 sintetiza os eixos de abordagem e as temáticas específicas que os compuseram. 
Figura 4: Proposta Contando Histórias, Resgatando Memórias.

\begin{tabular}{|c|c|c|c|}
\hline PROPOSTA & EIXO & ESPECÍFICO & OBJETIVO \\
\hline \hline $\begin{array}{c}\text { Contando Histórias, } \\
\text { Resgatando } \\
\text { Memórias }\end{array}$ & Quem sou eu? & $\begin{array}{c}\text { Identificação, rotina, } \\
\text { casa, escola, com quem } \\
\text { mora e o que gosta e não } \\
\text { gosta de fazer. }\end{array}$ & $\begin{array}{c}\text { Resgate dos aspectos } \\
\text { identitários }\end{array}$ \\
\hline & $\begin{array}{c}\text { Memórias } \\
\text { afetivas }\end{array}$ & $\begin{array}{c}\text { Cenários geográficose } \\
\text { alimentação, histórias, } \\
\text { cantigas e brincadeiras } \\
\text { do país de origem. }\end{array}$ & $\begin{array}{c}\text { Resgate de aspectos da } \\
\text { identidade cultural }\end{array}$ \\
\hline
\end{tabular}

Fonte: As Autoras (2020).

\#PraCegoVer: Tabela com quatro colunas: Proposta, Eixo, Específico, Objetivo. Na coluna Proposta o título Contando Histórias, Resgatando Memórias. Na coluna Eixo: Quem sou eu? Memórias afetivas. Na coluna Específico: Identificação, rotina, casa, escola, com quem mora e o gosta e não gosta de fazer: Cenários geográficos e alimentação, histórias, cantigas e brincadeiras do país de origem. Na coluna Objetivo: Resgate dos aspectos identitários: resgate de aspectos da identidade cultural.

\section{Estrutura Organizacional de um Encontro}

Os encontros com as crianças dividem-se em 10 momentos (Organização, Acolhimento, Brincadeiras Coletivas (Brincadeiras), Regras, História, Desdobramento, Lanche, Chamada das crianças pequenas (Chamadinha), Atividade e Despedida).

Primeiro Momento - Organização - o Pequenos do Mundo não possui uma sala própria e apropriada para o desenvolvimento das suas atividades; assim, antes da chegada da comunidade, precisamos preparar a sala para a ação. Para tanto, a equipe escalada para o dia organiza a sala de modo a dispor os materiais e os móveis de maneira adequada e segura para o acolhimento das crianças.

Segundo Momento - Acolhimento - com a sala organizada, iniciamos o acolhimento das crianças e de seus responsáveis. Aproveitamos a ocasião para retornos e trocas sobre ações passadas e o acompanhamento do desenvolvimento dos pequenos com a família, com a escola e com a comunidade. Todas as crianças recebem seus crachás de identificação produzidos por elas anteriormente. 
Terceiro Momento - Brincadeiras Coletivas (Brincadeiras) - dedicamos este momento a uma atividade lúdica, tendo por finalidade aclimar as crianças de todas as idades com o ambiente, com a equipe e com as outras crianças. Utilizamos este momento também para confecção dos crachás de crianças recém-chegadas.

Quarto Momento - Regras - tendo em vista que atuamos com o processo de convivência, elaboramos com as próprias crianças as regras de convivência; nesta etapa, relembramos com as crianças as regras e, caso necessário, são elaboradas novas regras. Abaixo, uma das crianças coloca na parede uma das regras.

Figura 5: Criança colocando uma regra na parede.

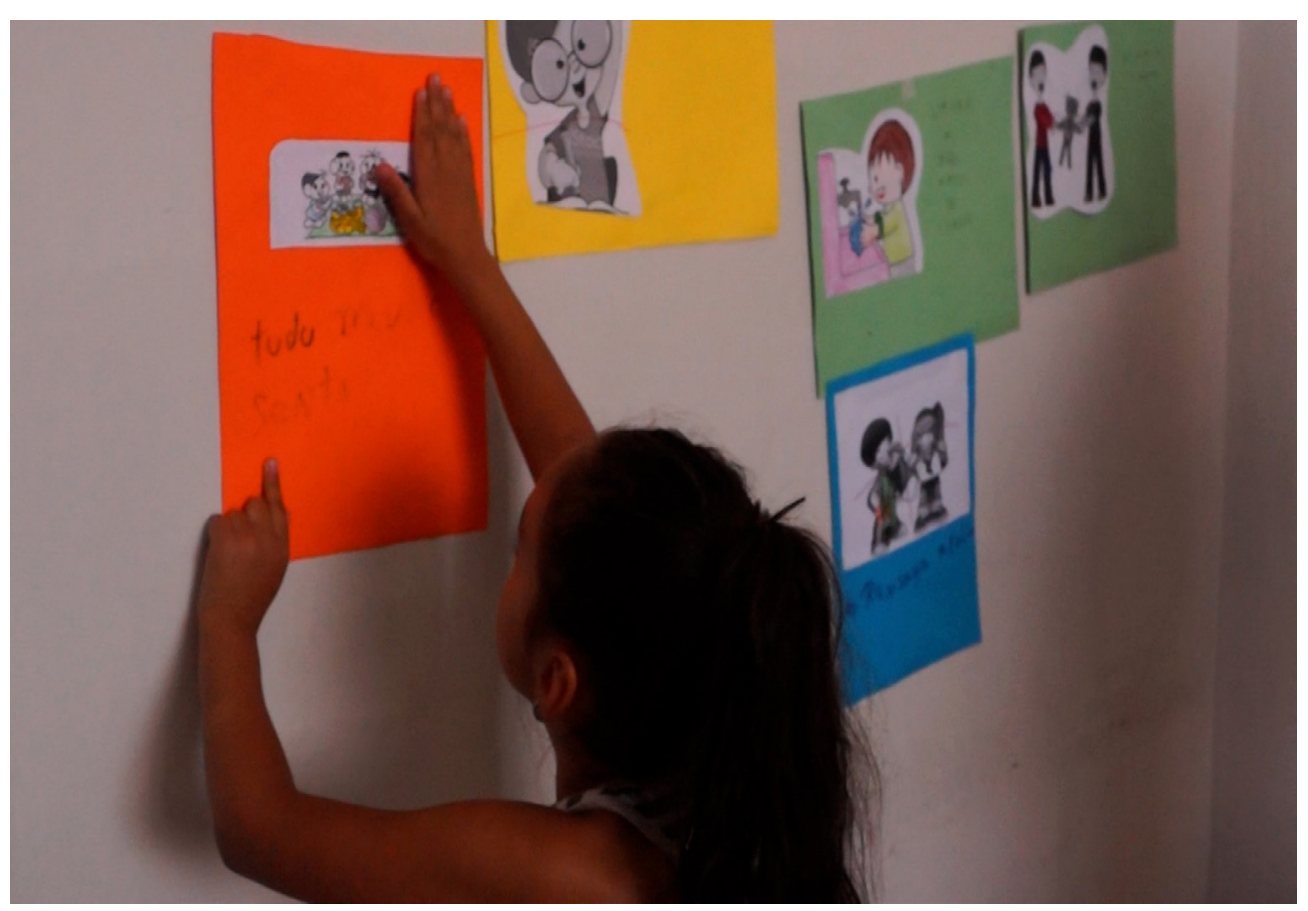

Fonte: Acervo do Pequenos do Mundo, 2019.

\#PraCegoVer: Fotografia colorida. Uma menina cola um cartaz na parede. Ela tem pele morena e cabelos castanhos e compridos. O cartaz é laranja, possui uma imagem da turma da Mônica e uma frase manuscrita.

Quinto Momento - História - um dos momentos centrais da ação. Nesse momento, as crianças sentam em círculo para escutar e participar da história contada pela equipe. Objetivando um envolvimento e um engajamento das crianças com a história a ser contada, nos caracterizamos, quando necessário, de acordo com os personagens de 
cada história, preparamos materiais lúdicos de apoio e arquitetamos uma ambientação. A figura 6 ilustra o momento de uma contação de histórias.

Figura 6: Contação de história.

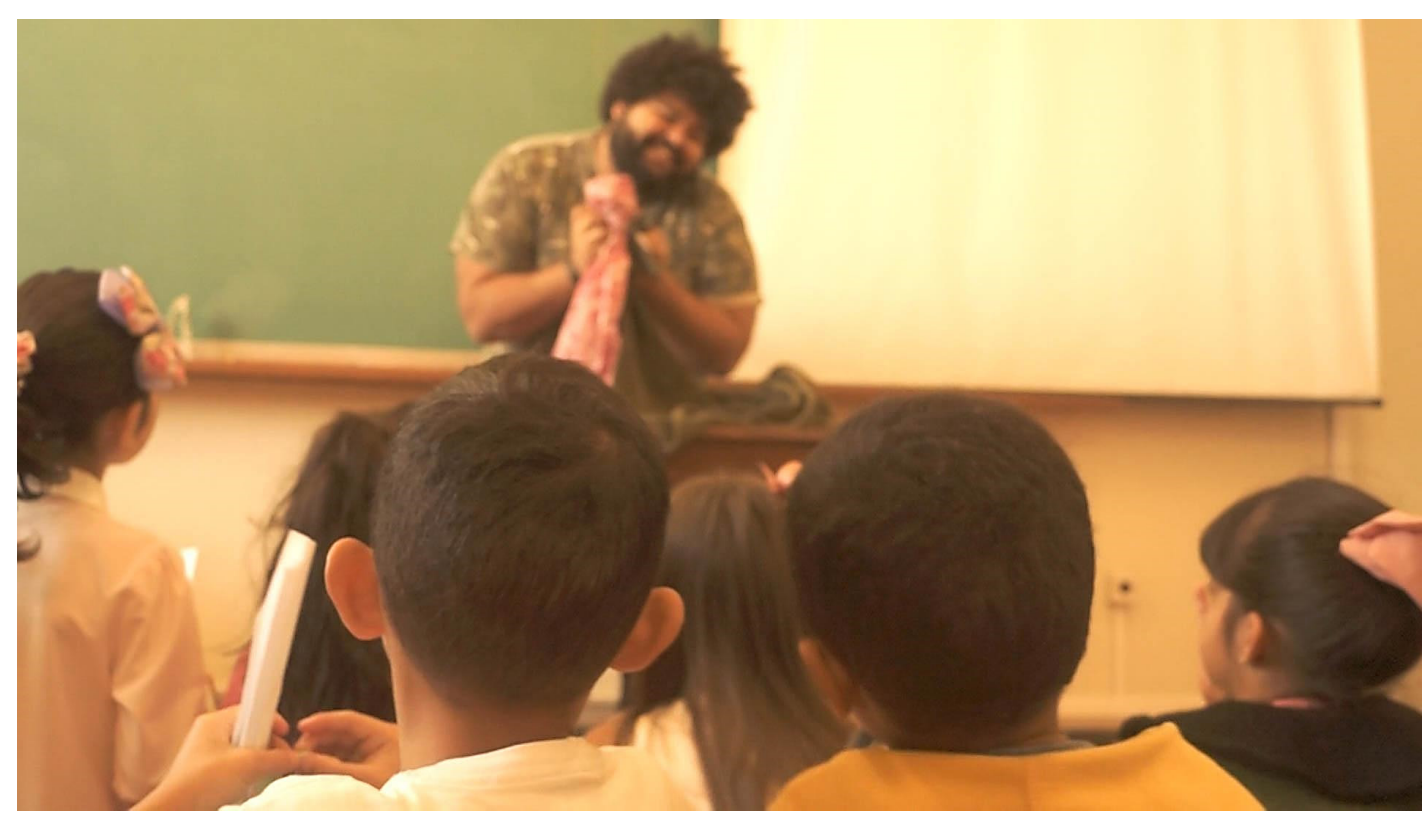

Fonte: Acervo do Pequenos do Mundo, 2019.

\#PraCegoVer: Fotografia colorida. Numa sala de aula, em frente ao quadro e de frente para a turma, um homem negro de cabelos encaracolados escuros e barba. Sua imagem está desfocada, ele segura algo contra o peito, parece um tecido rosa, sua cabeça está inclinada e ele sorri. Um grupo de crianças sentadas o observam atentamente.

Sexto Momento - Desdobramento - após o Quinto Momento, as crianças são desdobradas em duas turmas. Esta etapa objetiva o desenvolvimento das ações propostas respeitando as especificidades e as características de períodos de desenvolvimento distintos; desse modo, as crianças menores são levadas para outra sala, o, enquanto as maiores permanecem na sala inicial. É importante destacar que a divisão das crianças não é categórica, pois respeitamos o desejo que algumas crianças demonstram de permanecer com outras com as quais possuem algum vínculo afetivo/emocional.

$\mathbf{7}^{\mathbf{0}}$ Momento - Lanche-momento de compartilhamento e estreitamento dos laços, no qual as crianças conversam e trocam experiências ao mesmo tempo que partilham uma refeição. Enquanto as crianças lavam as mãos, a sala é preparada para a hora do lanche; o lanche é custeado e organizado pela própria equipe para as crianças. A figura 7 ilustra o momento do lanche com as crianças menores. 
Figura 7: Momento do Lanche com as crianças menores.

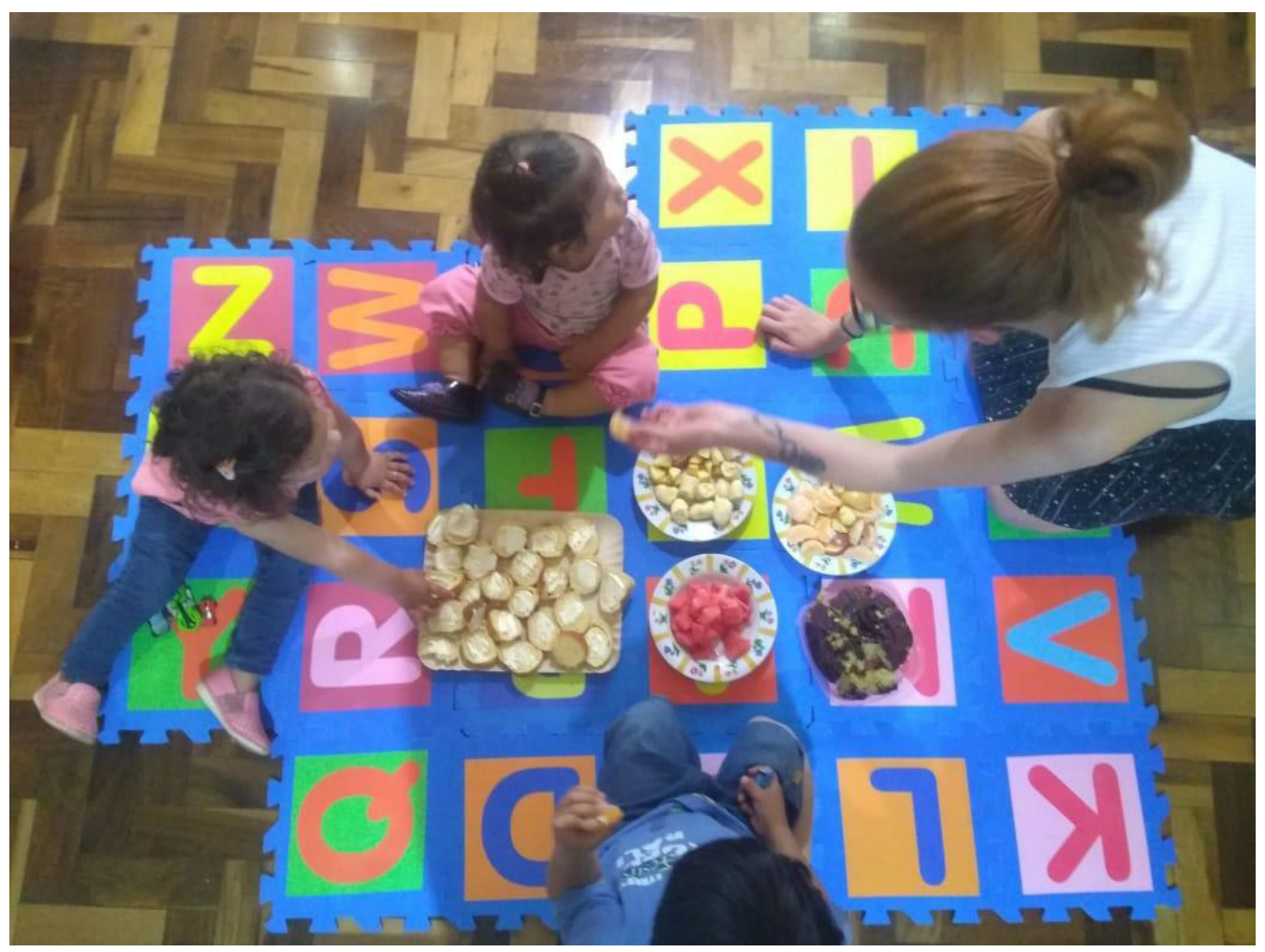

Fonte: Acervo do Pequenos do Mundo, 2019.

\#PraCegoVer: Fotografia colorida vista de cima. Sobre um tapete de EVA montado com peças retangulares das letras do alfabeto estão sentadas três crianças entre 1-3 anos e uma mulher. Entre elas há cinco pratos com alguns salgados, frutas picadas e em gomos. Duas crianças estão comendo e outra menor olha para o lado. A mulher oferece algo para a criança menor.

$8^{\circ}$ Momento - Chamada das crianças pequenas (Chamadinha) - momento de (re)conhecimento de si e dos colegas. Esta atividade é realizada com as crianças menores (que ainda não sabem ler) e proporciona uma conexão acerca da sua identidade e da identidade dos colegas. A chamada é feita verbalmente, mas é construída fisicamente com as crianças; elas são chamadas pelo nome e acrescentam detalhes (como a bandeira de seu país de origem, desenhos e figurinhas que expressavam sentimentos) em sua ficha de identificação, a qual contém, inicialmente, sua foto de rosto e seu nome.

$9^{\circ}$ Momento - Atividade - momento dedicado a(s) atividade(s) sistematizada(s) com o objetivo de proporcionar reflexões, estabelecimento de relações, sensibilizar as crianças sobre a temática trabalhada na contação de história e propiciar produção material/ 
simbólica acerca do tema. Ressaltamos que essa(s) atividade(s) e reflexões são trabalhadas de acordo com período de desenvolvimento da criança e com a ação (micro ou macro).

$\mathbf{1 0}^{\mathbf{0}}$ Momento - Despedida - Momento de reencontros e despedidas. Primeiro, as duas turmas são reagrupadas em uma única turma, possibilitando momentos de recreação em conjunto enquanto aguardam as famílias saírem das aulas de português. Após a saída de todas as crianças, reorganizamos a sala, guardando os materiais do projeto e dispondo a sala novamente para as aulas da graduação/pós-graduação.

A Figura 8 sintetiza a dinâmica, os processos e a organização envolvida em cada encontro do Pequenos do Mundo.

Figura 8: Fluxo Organizacional de um Encontro.

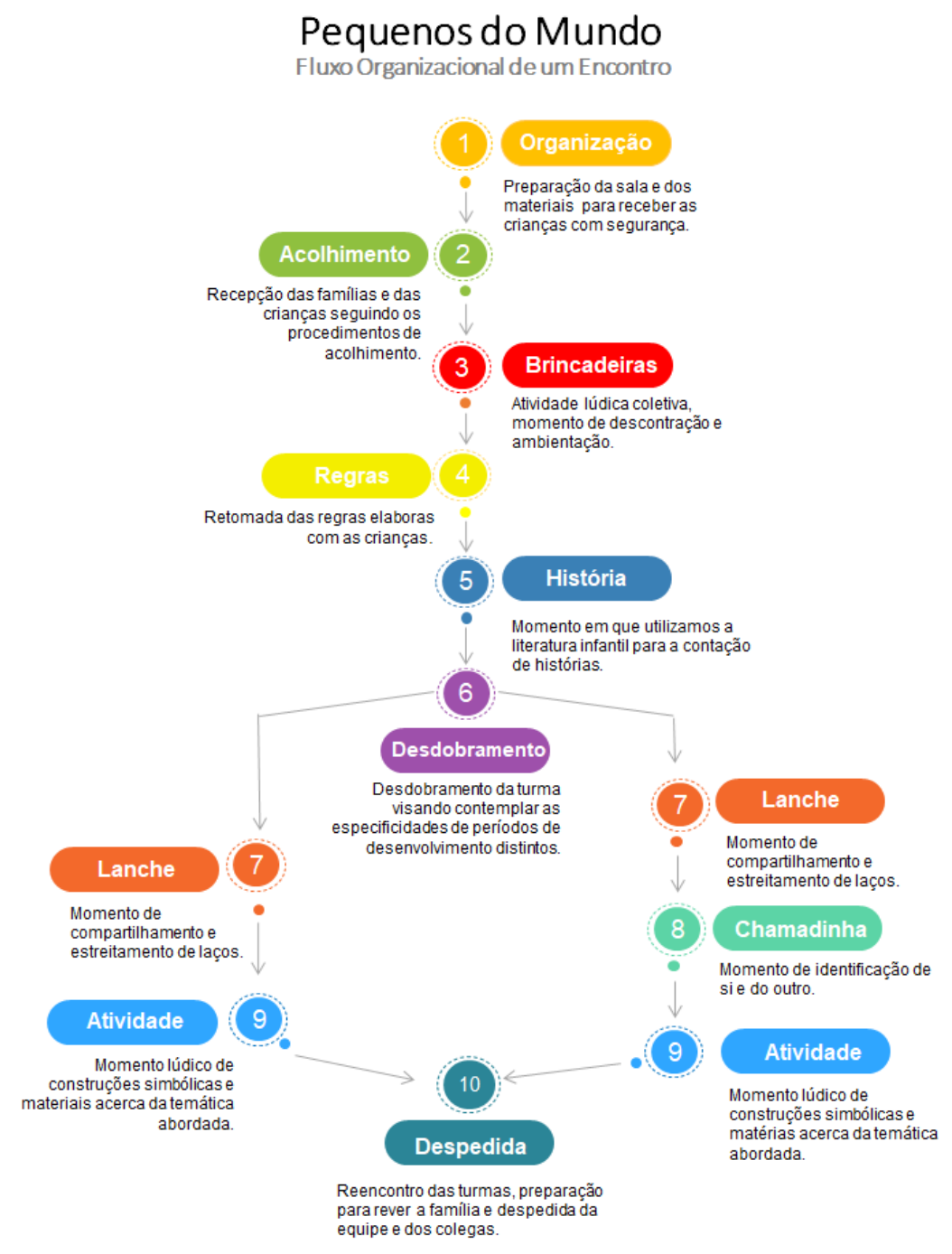

Fonte: As Autoras (2020). 
\#PraCegoVer: Esquema iniciando na vertical com seis círculos coloridos, do sexto círculo se desdobram dois círculos à esquerda e três à direita, ambos culminam no círculo dez que encerra o esquema. Título: Fluxo organizacional de um encontro. Círculo 1, amarelo escuro, Organização preparação da sala e dos materiais para receber as crianças com segurança. Círculo 2, verde, Acolhimento: recepção das famílias e das crianças seguindo os procedimentos de acolhimento. Círculo 3, vermelho, Brincadeiras: atividade lúdica coletiva, momento de descontração e ambientação. Círculo 4, amarelo, Regras: retomada das regras elaboradas com as crianças. Círculo 5, azul escuro, História: momento em que utilizamos a literatura infantil com a contação de histórias. Círculo 6, roxo, Desdobramentos: desdobramento da turma visando contemplar as especificidades de períodos de desenvolvimento distintos. Tanto do lado direito como do esquerdo, círculo 7, laranja, Lanche: momento de compartilhamento e estreitamento de laços. Lado direito, círculo 8. Chamadinha: momento de identificação de si e do outro. Tanto à esquerda como à direita, círculo 9, azul claro, Atividade: momento lúdico de construções simbólicas e matérias acerca da temática abordada. No centro, círculo 10, verde escuro, Despedida: reencontro das turmas, preparação para rever a família e despedida da equipe e dos colegas.

\section{Ações micro - Cenários geográficos}

A título de exemplo, uma das ações micro desenvolvidas na proposta Contando Histórias, resgatando memórias, no eixo "Memórias Afetivas", foi "Cenários geográficos', cujo objetivo foi trabalhar as noções de territorialidade, elementos culturais, distâncias geográficas e trajetórias de migração entre os países de origem e o Brasil. Para isso, selecionamos a obra Um outro país para Azzi, de Sarah Garland (2012), que conta o processo migratório da personagem infantil Azzi e de sua família. A história abarca temáticas como saudades, o aprendizado de uma nova língua, adaptação a uma nova casa, cidade e escola.

A partir da história de Azzi, preparamos duas atividades de produções materiais, uma para as crianças maiores e outra para as menores, já que é fundamental um planejamento distinto, em consonância com seu período do desenvolvimento. A partir da tríade conteúdo-forma-destinatário, proposto por Martins (2013), entendemos que determinado conteúdo deva ser oferecido considerando as características e especificidades da forma dominante de vinculação da criança com o mundo. Sendo assim, para as maiores, como primeiro passo, a equipe desenvolveu a representação de um Mapa Mundi de grandes proporções em TNT, delimitando e identificando os países das crianças ou de sua família; ao colocar em prática a ação, propusemos às crianças primeiro identificar os seus países de origem, ou de suas famílias, com um alfinete e seu nome. Após essa primeira etapa, ligamos os alfinetes com um barbante até o Brasil para mostrar às crianças a trajetória do processo migratório.

É importante salientar que o processo migratório não é somente a rota do país de origem para o Brasil, posto que é comum a presença de países de passagem durante o processo, e dependendo da consciência/entendimento de seu processo migratório, a criança pode levantar essa questão aos adultos durante a discussão. As crianças durante a 
atividade compartilharam com o grupo como ocorreu essa trajetória até o Brasil: de carro, avião e ônibus.

Figura 9: Mapa Mundi.

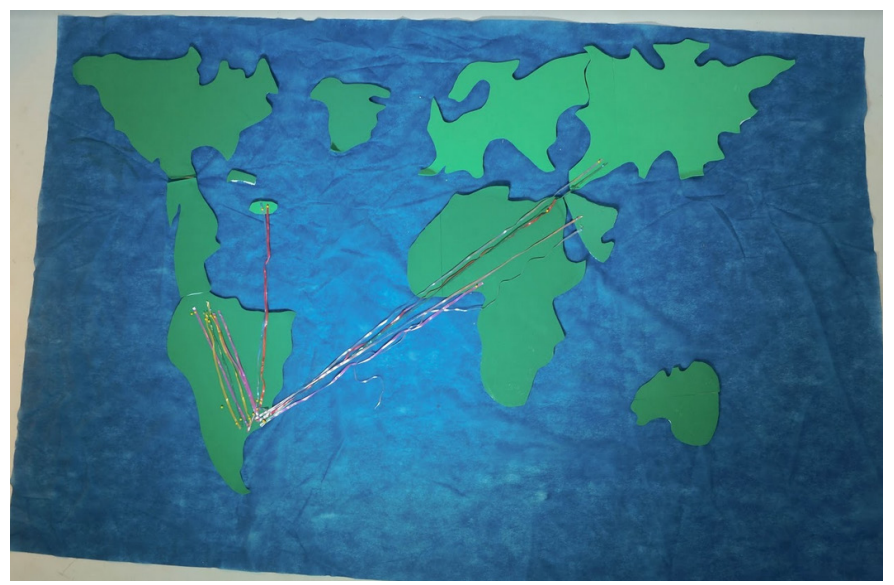

Fonte: Acervo do Pequenos do Mundo, 2019.

\#PraCegoVer: Fotografia colorida. Vista de cima. Os continentes recortados em EVA verde estão sobre um TNT retangular azul escuro. Do sul do Brasil, mais especificamente do Paraná saem fitas coloridas para vários lugares do planeta. Algumas indicam a Venezuela, a Colômbia, o Haiti, países ao norte da África e da Ásia.

Figura 10: Detalhe do Mapa Mundi.

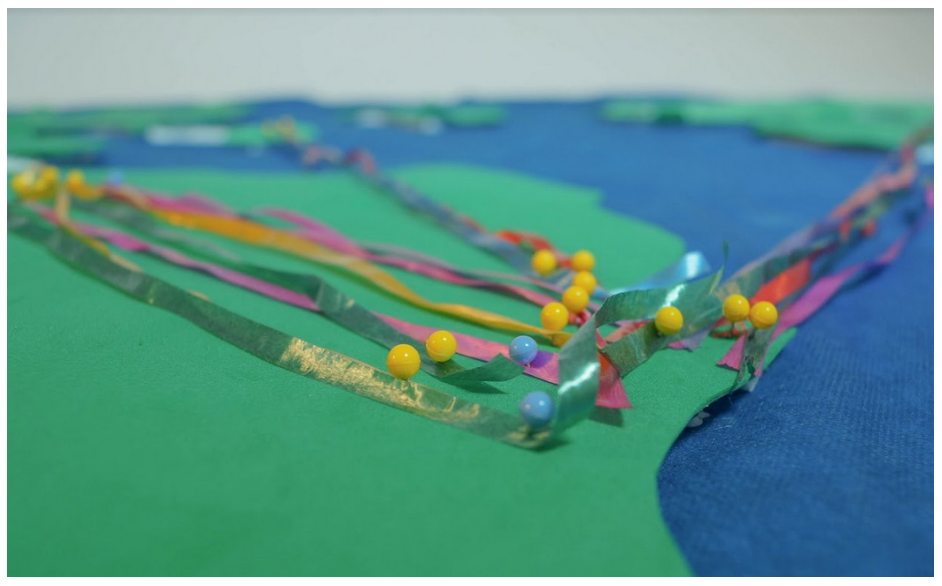

Fonte: Acervo do Pequenos do Mundo, 2019.

\#PraCegoVer: Fotografia colorida. A mesma fotografia da Figura 9, focaliza em primeiro plano várias fitas presas no EVA com alfinetes coloridos. Elas saem do Paraná, sul do Brasil. 
Após essa atividade em grupo, disponibilizamos às crianças massinhas de modelar e argila para que elas pudessem construir algum objeto que lembrassem do país de origem para guardarem na caixa de memórias, a ser explicada a seguir. Abaixo, a figura 11 ilustra uma comida típica da Venezuela, produzida por uma criança; já a figura 12 ilustra as produções de um menino venezuelano representando sua família que ficou no país de origem (forma humana), o afeto que tem por ela (coração) e o cachorro que não pôde trazer junto para o Brasil (osso).

Figura 11: Empanadas venezuelanas.

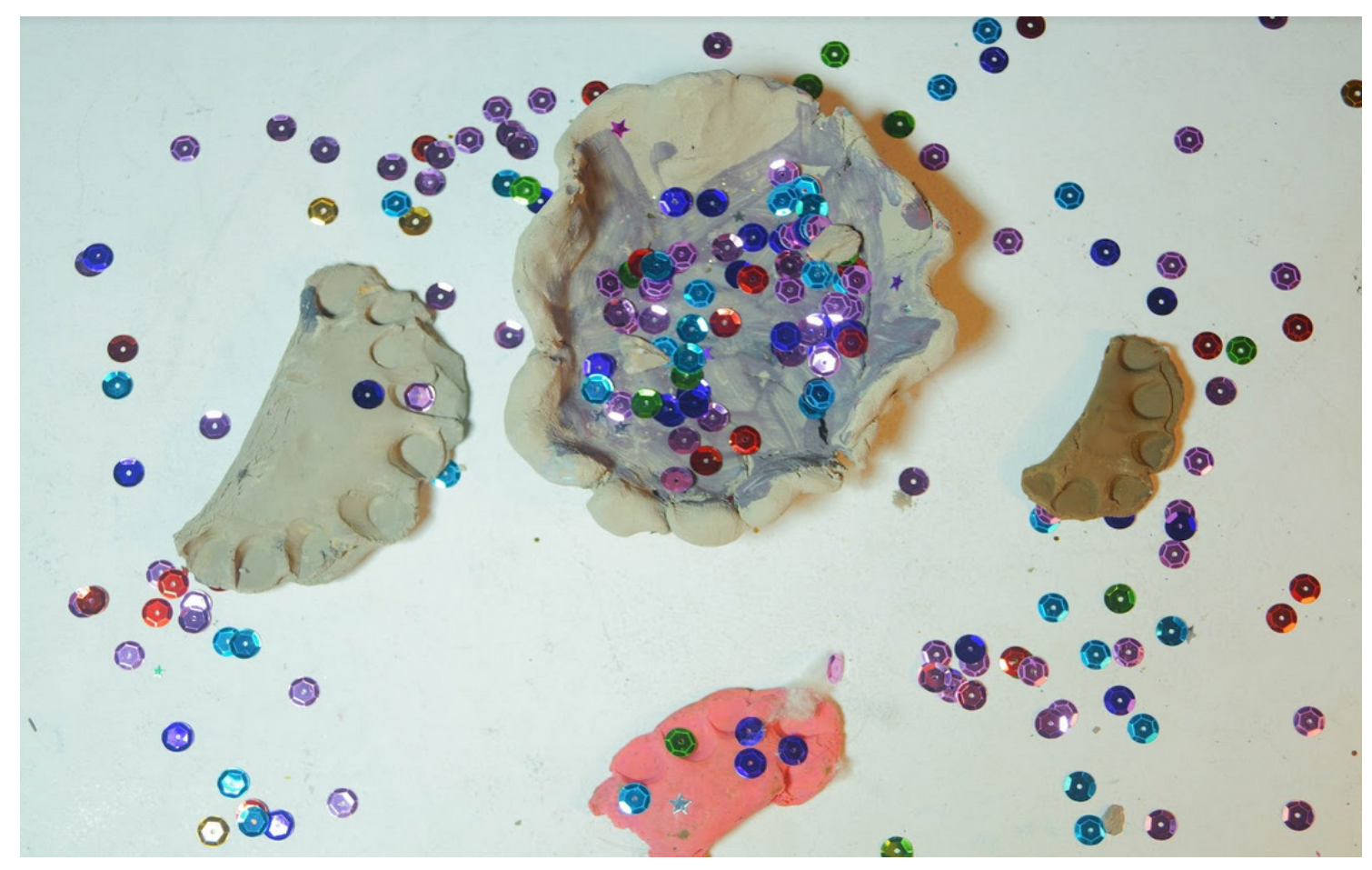

Fonte: Acervo do Pequenos do Mundo, 2019.

\#PraCegoVer: Fotografia de elementos produzidos com massinha de modelar e argila. Algumas empadas em formato de pastéis e um prato de uma comida típica. Várias lantejoulas enfeitam o trabalho. 
Figura 12: Representação da família, do afeto e do osso do cachorro.

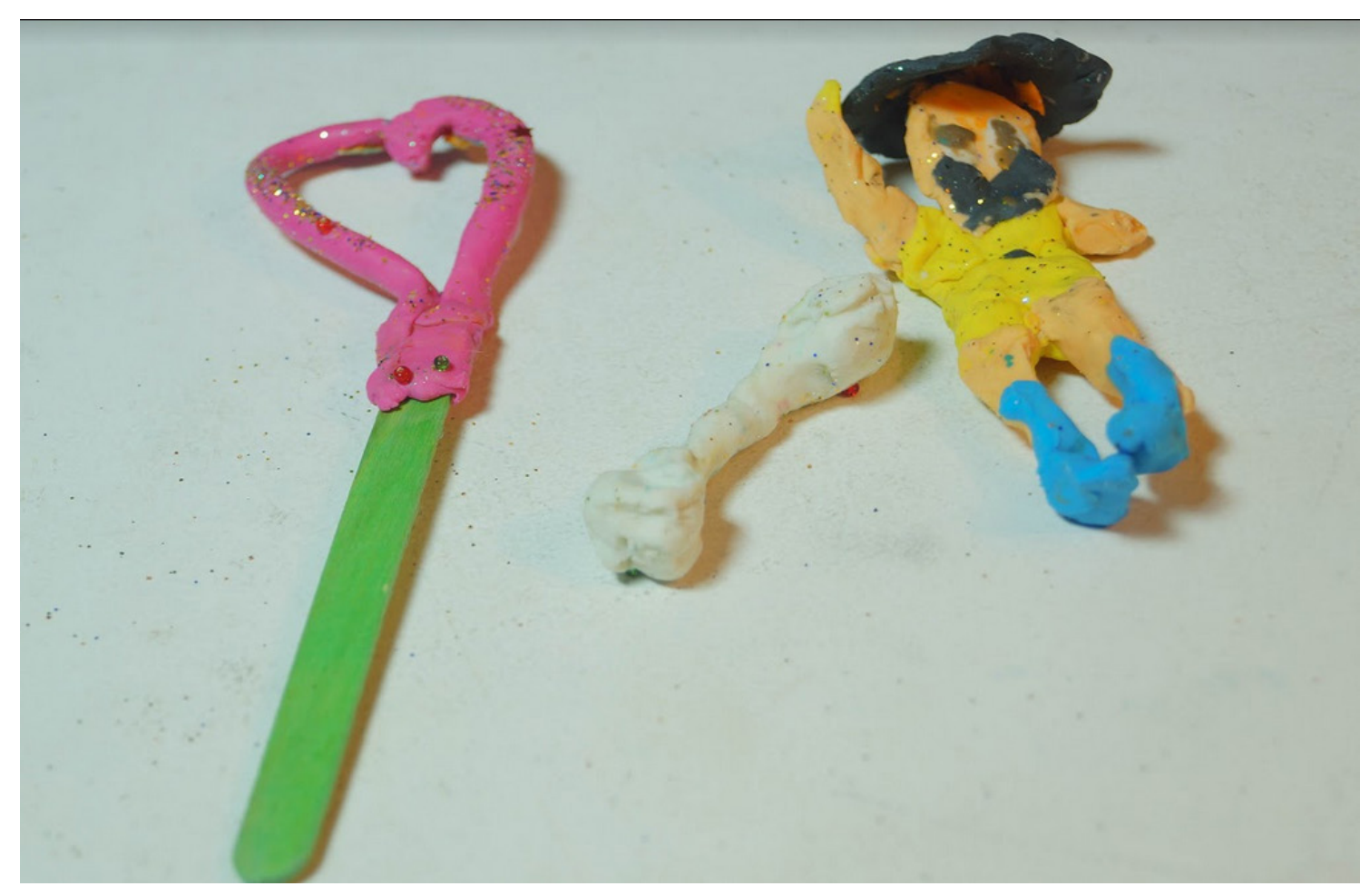

Fonte: Acervo do Pequenos do Mundo, 2019.

\#PraCegoVer: Fotografia colorida. Vista de cima. À esquerda um palito de sorvete, na ponta o contorno de um coração confeccionado com massinha de modelar, ao centro um osso branco, à direita um homem com chapéu preto, barba, blusa amarela, calça bege e botas azuis.

Para as crianças menores, elaboramos outro mapa e propusemos uma atividade de pintura com as mãos; cada criança pintou o mapa com suas mãos de maneira livre. Tivemos a intenção de que a criança conhecesse o que era um mapa de uma forma lúdica e divertida. O foco, no entanto, não era que ela desenvolvesse conceitos de territorialidade formais e/ou abstratos. 
Figura 13: Mapa Mundi para as crianças menores.

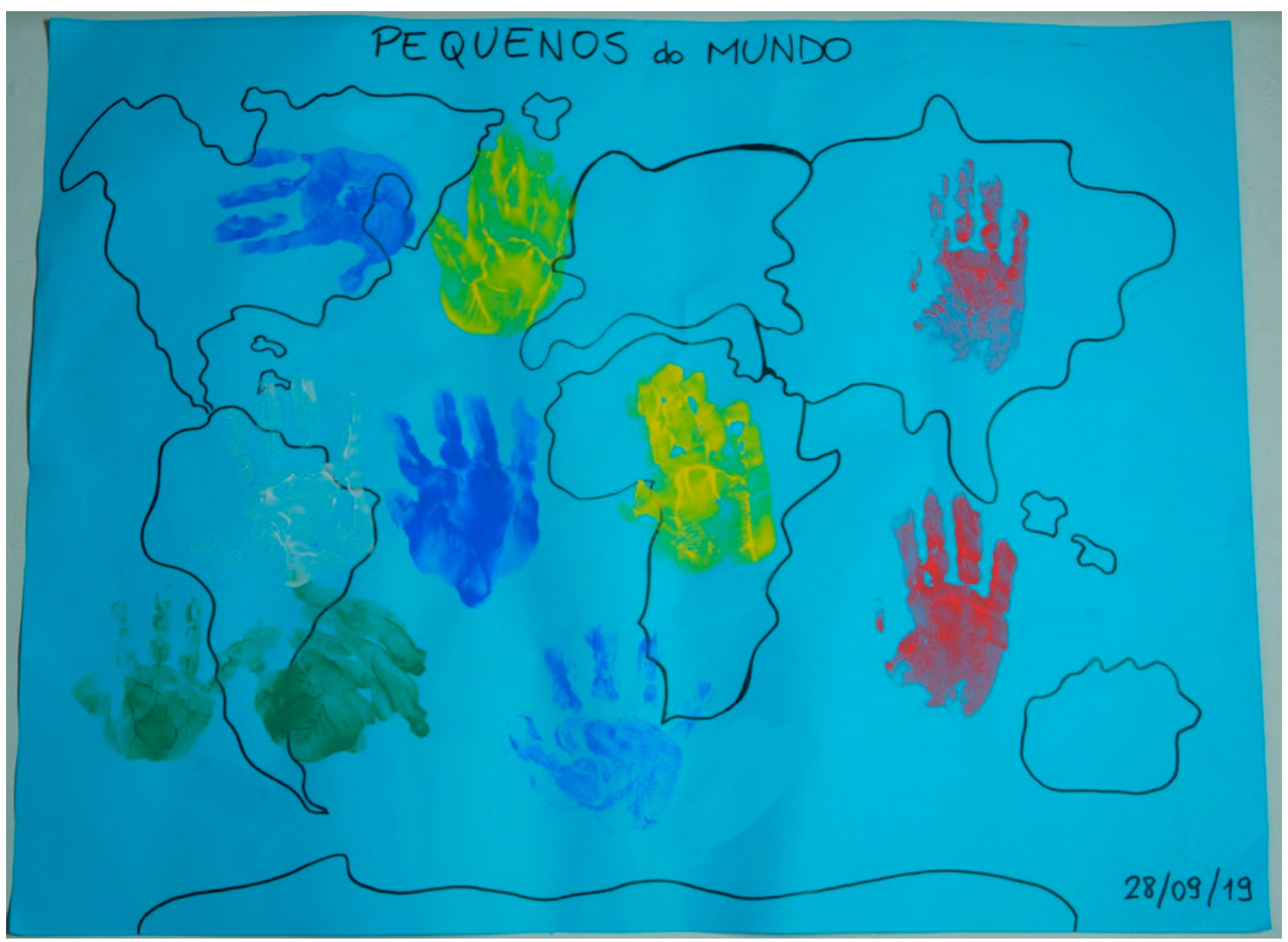

Fonte: Acervo do Pequenos do Mundo, 2019.

\#PraCegoVer: Fotografia colorida. Vista de cima. Um cartaz na cor azul com o contorno dos continentes em preto. Espalhado por todo o mapa carimbos coloridos das mãos de crianças. No canto inferior direito a data $28 / 09 / 19$.

\section{Ação macro - A Caixa de Memórias}

A Caixa de Memórias foi uma ação macro proposta para as crianças a partir do livro A menina que abraça o vento, de Fernanda Paraguassu (2017). Nele, a personagem principal é Mersene, uma menina refugiada da República Democrática do Congo, que migra para o Brasil. De uma forma lúdica e de fácil entendimento, o livro conta o processo migratório da personagem, de imediato reconhecido pelas crianças pela similaridade com as suas próprias histórias. Para a contação de história (Quinto Momento), confeccionamos uma Caixa de Memórias para Mersene. As memórias relatadas pela personagem foram materializadas a partir de sua caixa, elemento novo adicionado à história. Tal como 
Mersene, as crianças foram instigadas e convidadas a construir a sua própria Caixa de Memórias a partir de uma caixa de sapato. Explicamos às crianças que a caixa iria acompanhá-las até o fim do ano e que nela poderiam ser colocados objetos pessoais de cunho afetivo, como fez Mersene na história reelaborada pela equipe. Disponibilizamos às crianças diversos materiais para que elas pudessem decorá-las do seu próprio jeito.

Figura 14: Caixa de memórias de uma das crianças.

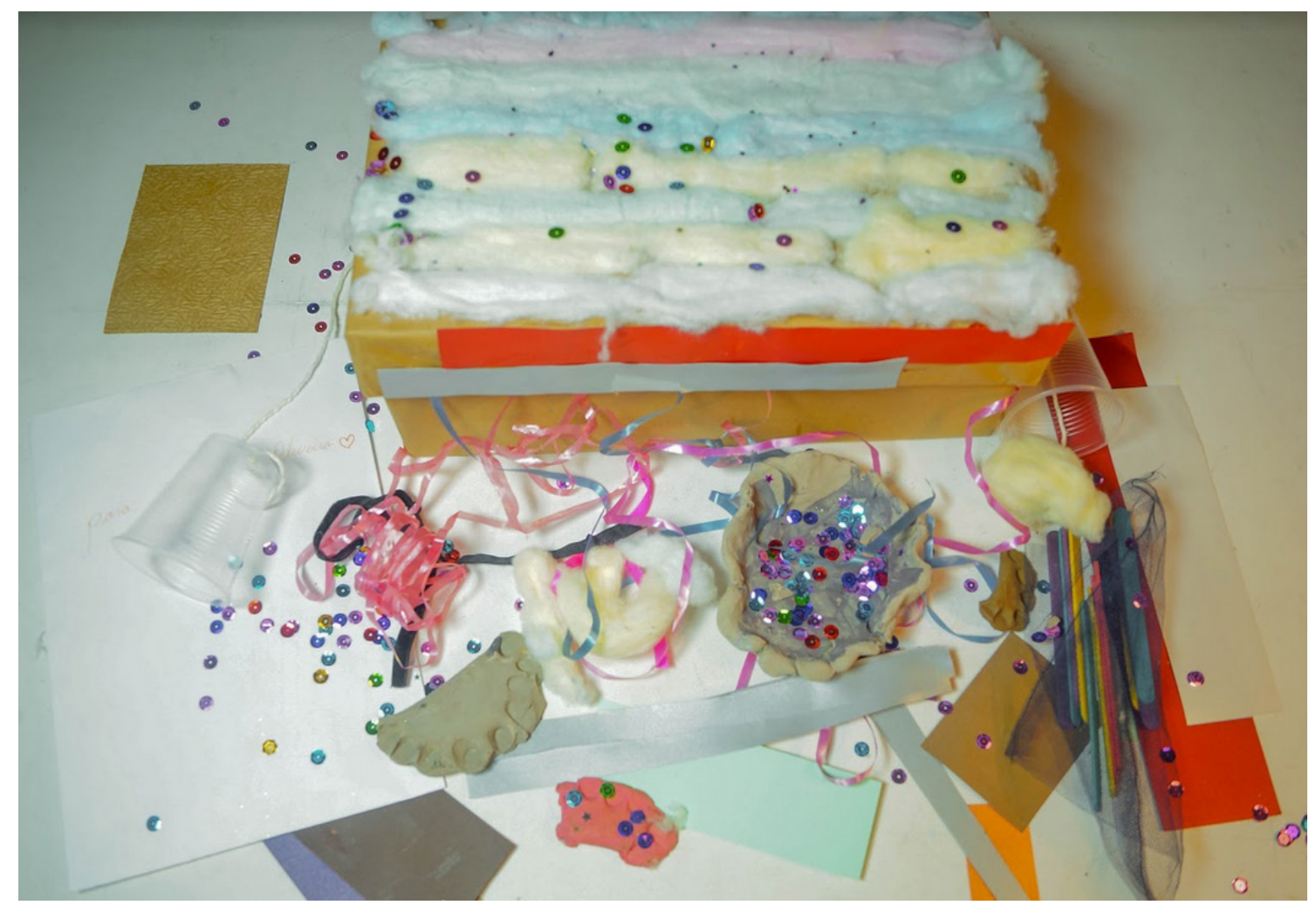

Fonte: Acervo do Pequenos do Mundo, 2019.

\#PraCegoVer: Fotografia colorida. Vista de cima. Caixa de papelão com a tampa toda enfeitada de algodão colorido e lantejoulas. Em volta vários objetos feitos com massinha de modelar, fitas coloridas, copo descartável transparente, palitos coloridos, pedaços de tecido e cartolinas.

\section{AS CRIANÇAS E SUAS HISTÓRIAS: PRODUÇÕES SIMBÓLICAS E/OU MATERIAIS DAS MEMÓRIAS AFETIVAS}

Nesta seção, trazemos algumas das produções simbólicas e/ou materiais elaboradas pelas crianças migrantes participantes do projeto Pequenos do Mundo, de 
modo a considerar os dois grandes eixos: Quem sou eu? e Memórias Afetivas. Devido à quantidade de materiais resultantes de cada eixo, não iremos expô-los em sua totalidade; optamos por trazer uma seleção que contemplasse e ilustrasse as concepções e reflexões discutidas neste artigo. Ademais, ainda no que concerne às produções simbólicas apresentadas e discutidas nesta seção, salientamos que foram expressas pelos pequenos migrantes durante as ações desenvolvidas.

O primeiro eixo desta categorização elaborada é o Quem sou eu?, que engloba memórias das crianças sobre aspectos de seu cotidiano (como sua família, sua rotina e sua escola), sobre seus interesses e também aspectos culturais com os quais ela se identifica e nos quais se reconhece. Este eixo foi subdividido em outros dois a partir das produções das crianças, sendo estes Pátria e Linguístico. Em relação ao primeiro, ao longo do Contando histórias, resgatando memórias, foi frequente as crianças incluírem em seus desenhos as bandeiras de seus países de origem. Durante uma atividade, uma menina de oito anos disse que as suas cores favoritas são "as da bandeira da Venezuela". Em outra atividade, na qual montamos quebra-cabeças com as bandeiras, uma criança venezuelana de três anos exclamou "É aqui que eu vivo!" ao ver a de seu país. Com base nestes dois relatos, podemos perceber as diferenças de entendimento sobre a questão migratória em diferentes períodos do desenvolvimento. Percebemos que, em relação à criança mais nova, a mais velha consegue expressar compreensões mais abstratas sobre o que é um país e sobre a mudança para o Brasil.

No encontro em que discutimos sobre composições familiares, uma menina de sete anos incluiu a bandeira do Irã e uma mesquita no desenho que fez de sua família. Ainda, disse que a palavra "família" em português foi aprendida nesta ocasião.

Vale salientar, que segundo Vigotski (1999), durante a infância a arte se aproxima da brincadeira, como a cantiga infantil se aproxima do jogo. O desenho "pode expressar diretamente os estados de ânimo e as inquietações da alma" (VIGOTSKI, 1999, p.326), em que por meio de esquemas a criança se apropria e representa a realidade. Assim como a cantiga brinca com a palavra, o desenho brinca com a linha. Na infância, o desenho é uma das principais manifestações da atividade criadora (VIGOTSKI, 2018b) e de expressão de como a criança entende e se relaciona com o mundo. Assim, utilizar o desenho como um recurso para o trabalho com as crianças migrantes justifica-se à medida em que esta produção possibilita narrar sobre suas vivências e situar-se nelas. 
Figura 15: Desenho da família, a bandeira do Irã e a mesquita.

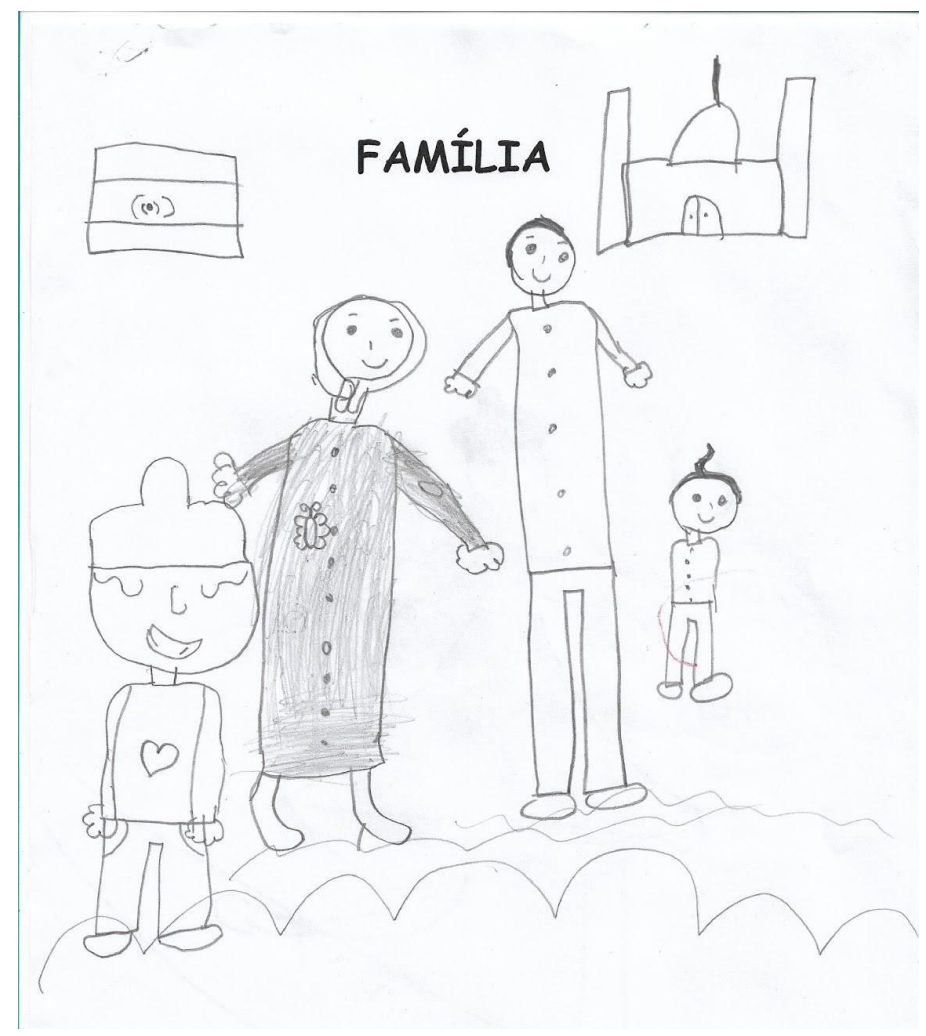

Fonte: Acervo do projeto, 2019.

\#PraCegoVer: Desenho na cor preta. Título acima e centralizado: Família. Canto superior esquerdo uma bandeira e superior direito uma mesquita. No centro da folha e ocupando quase todo o espaço, da esquerda para a direita: um menino sorridente, ele usa um objeto na cabeça, uma camiseta com um desenho de coração e uma calça. Uma mulher com vestido escuro, no vestido o detalhe de uma borboleta. Um homem alto usa uma camisa e uma calça e uma menina menor, usa uma blusa, uma calça e o cabelo amarrado.

Ainda quanto ao subeixo Pátria, ao confeccionar a sua caixa de memórias, uma menina de oito anos contou que usou as cores verde e vermelho, que segundo ela "são cores dos partidos políticos da Colômbia". Esta memória nos aponta como as crianças desde muito cedo são capazes de elaborar compreensões sobre o contexto no qual vivem, com base em acontecimentos que as afetam e em comentários feitos por familiares ou pessoas próximas. Como relembram Braga e Smolka (2020), a subjetividade é constituída na relação com o outro e as experiências compartilhadas compõem o conhecimento que a criança tem de si mesma e do mundo. Deste modo, ao decorar sua caixa, a menina colombiana expressa memórias de aspectos do contexto político de seu país de origem que são acessíveis à sua compreensão. 
Figura 16: Caixa de memórias com as cores de partidos políticos.

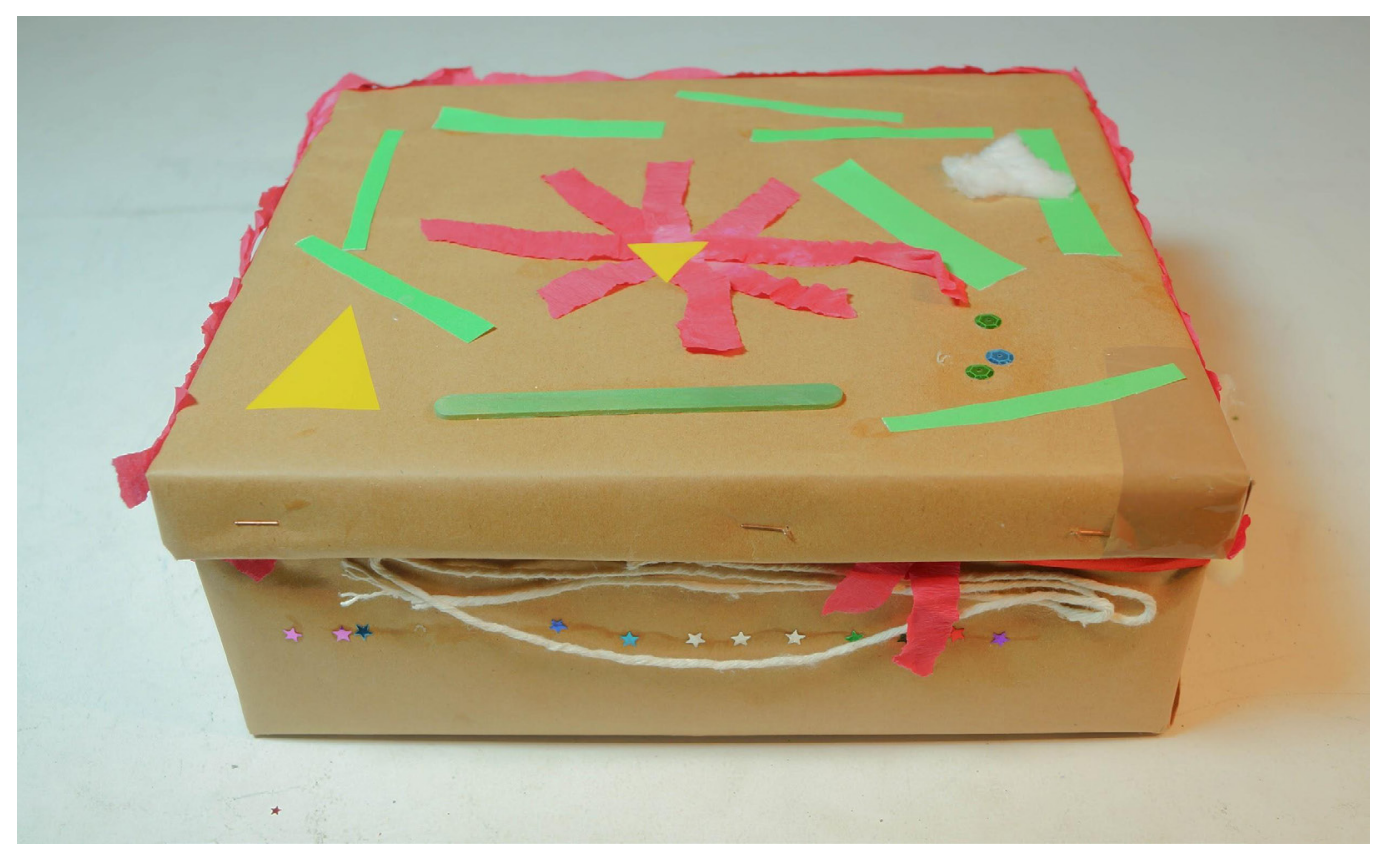

Fonte: Acervo do Pequenos do Mundo, 2019.

\#PraCegoVer: Fotografia colorida. Vista de cima. Uma caixa de papelão encapada e enfeitada. Na tampa várias tiras de papel verde, vermelho e amarelo. Em uma das laterais barbantes, estrelinhas e fitas vermelhas.

No que diz respeito ao subeixo Linguístico, notamos a importância do idioma materno para as crianças durante as atividades. Uma menina venezuelana de sete anos, durante a escrita de uma carta direcionada para a família, demonstrou o desejo de escrevêla em espanhol. As crianças também relembram de situações nas quais vivenciaram dificuldades em entender ou serem entendidas em português. Depois da apresentação da peça teatral Que meleca! Sumiram as letras da biblioteca, da Inabalável Companhia, uma menina venezuelana de três anos expressou sua dificuldade em ser compreendida tanto em espanhol quanto em português. Na escola, suas colegas pediam a ela que "fale em português!", quando ela já está falando nessa língua; em casa, ela diz que "minha mãe não me entende quando conversamos em espanhol". É importante notar que o bilinguismo pode ser um fator potencializador do desenvolvimento da criança, pois amplia a sua capacidade de compreender o mundo e de se expressar nele (VIGOTSKI, 2005). No entanto, como ressalta o autor, também pode gerar conflitos em seu cotidiano, especialmente na escola, a depender da mediação pedagógica, razão por esta ter uma posição ainda mais central nestes casos. 
Figura 17: Carta para a mãe escrita em espanhol.

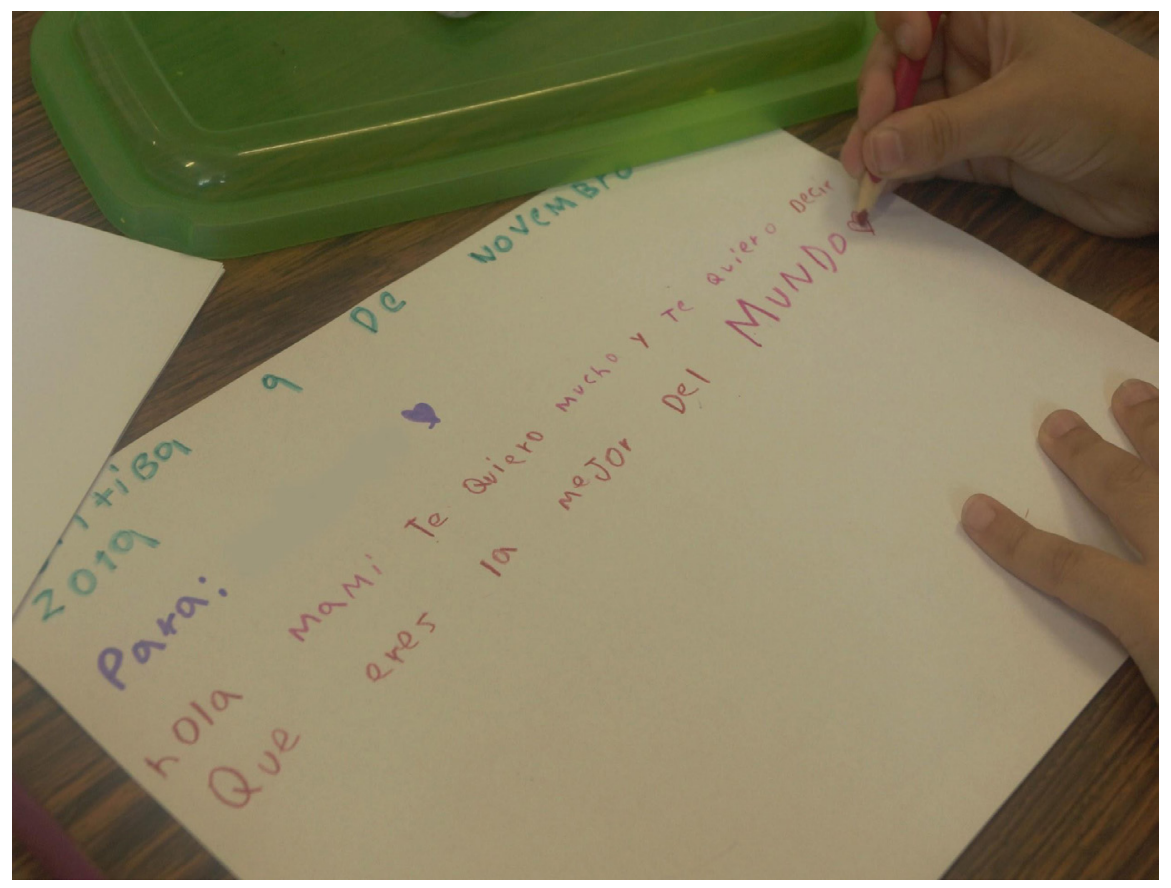

Fonte: Acervo do Pequenos do Mundo, 2019.

\#PraCegoVer: Fotografia colorida. Em primeiro foco, sobre uma mesa, uma mão escreve com lápis de cor em uma folha de sulfite, a outra mão segura o papel. Ao lado uma tampa verde de um pote. Na folha de sulfite lemos: Curitiba, 9 de novembro de 2019. Abaixo a escrita: Para e o desenho de um coração. Mais abaixo a mensagem: Hola mami, te quiero mucho y te quiero decir que eres la mejor del mundo.

O segundo eixo, que trata das Memórias afetivas, como já apresentado, considera memórias da criança referentes aos cenários geográficos, à alimentação, às histórias, aos costumes, às cantigas e às brincadeiras do país de origem. A partir dos relatos das crianças, este eixo foi subdividido nos subeixos Comida, Brinquedos/Pertences, Família e Amigos e Trajetória. A primeira categoria aparece, por exemplo, na fala de uma menina venezuelana de cinco anos ao afirmar que "minha comida preferida na Venezuela era pescados". Durante outra atividade, uma menina venezuelana de seis anos relatou que "minha comida favorita é pão-de-queijo. Comi pela primeira vez em Boa Vista na casa da minha tia", uma vez que "não tinha comida na Venezuela". As comidas, portanto, retomam experiências afetivas, lugares e histórias que fazem parte de uma memória e situação específica. Estes conteúdos vividos expressam a mobilização de sentimentos e a atribuição de sentido pela criança. 
Nos relatos é possível observar a percepção das crianças sobre o próprio contexto em que estão inseridas, uma percepção que evidencia a condição de vulnerabilidade do percurso migratório. Esta percepção é construída a partir da relação com a família sobre a realidade objetiva. No trabalho desenvolvido com as crianças, há um cuidado com relação aos conteúdos que podem desencadear emoções ou retomar momentos sensíveis a elas. Portanto, proporcionamos a comunicação a partir do vínculo com a equipe, possibilitando que as crianças se sintam confortáveis com o compartilhamento de certos relatos individuais.

Com relação às memórias relacionadas aos Brinquedos/Pertences, fazemos referência à fala de uma menina iraniana de sete anos em que relata sentir muita falta dos "brinquedos que ficaram no Irã". Em outro momento, uma menina venezuelana, de três anos, reconheceu um brinquedo de labirinto pertencente ao projeto e afirmou que tinha um igual na Venezuela. A brincadeira e o lúdico - processo em que os brinquedos têm lugar de destaque - adquirem um papel fundamental nesta atuação, pois compreendemos que esta atividade, como, por exemplo, o jogo de papéis, possuem uma função importante para a organização e orientação da criança diante das relações sociais e da realidade. É na brincadeira que é possível elaborar significados, desenvolver a imaginação e o pensamento, recordar e reconstruir eventos passados (RIOS; ROSSLER, 2017).

No terceiro subeixo, Família e Amigos, destacamos quatro relatos. Uma menina iraniana, de sete anos, compartilhou que a diferença de comemorar seu aniversário no Irã era que "Lá tinham muitas pessoas em minha festa, mas no Brasil ninguém sabia". Da mesma forma, durante uma atividade de escrita de cartas para um outro grupo de crianças migrantes, uma menina venezuelana de seis anos, não queria escrever para as crianças que não conhecia, mas sim para seus amigos que estavam na Venezuela. Na mesma atividade, uma menina de três anos, também venezuelana, disse que gostaria de fazer a sua carta para uma amiga da escola que também era de outro país. Em uma outra atividade de escrita de cartas, desta vez para as famílias, um menino venezuelano de quatro anos, escreveu uma carta dizendo que amava o pai que tinha ficado na Venezuela (Figura 18). Todas essas situações ilustram como os vínculos afetivos com familiares e amigos são relevantes no conteúdo expressado pelas crianças, tanto visualmente quanto pela fala. São relatos marcados pela saudade daqueles que deixaram, das situações que viveram antes da migração e do vínculo com quem se reconhecem. 
Figura 18: Carta de menino venezuelano para o pai.

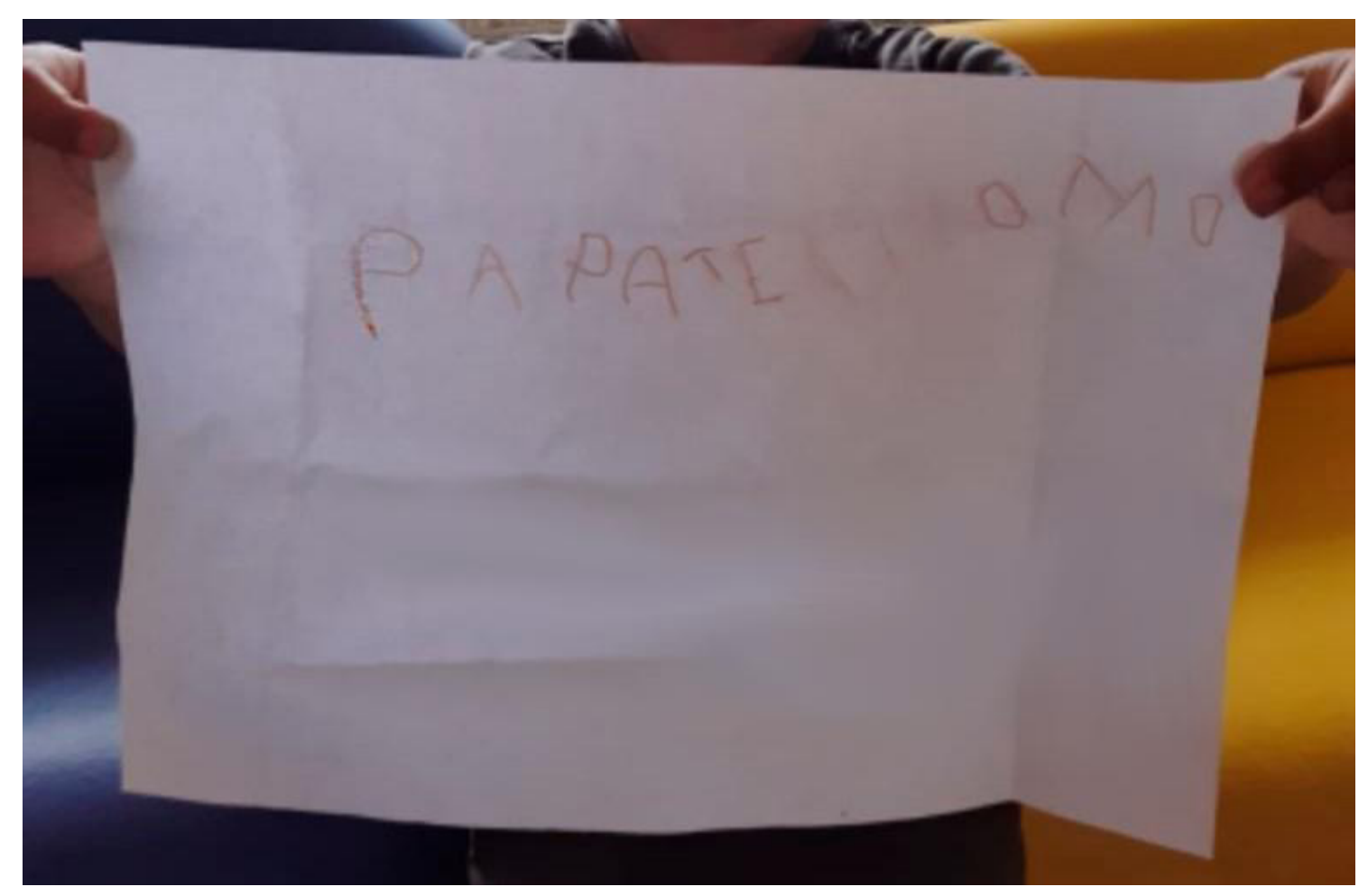

Fonte: Acervo do Pequenos do Mundo, 2019.

\#PraCegoVer: Fotografia colorida. Uma criança segura a sua frente uma folha de sulfite com a frase: Papa te amo. Não aprece o rosto da criança, apenas seus dedinhos segurando a folha.

O quarto subeixo refere-se à Trajetória e contempla relatos que se referem ao reconhecimento geográfico do percurso migratório. A título de exemplo, uma menina venezuelana de seis anos disse que pegou três aviões para chegar ao Brasil. Em outro caso, um menino venezuelano de cinco anos desenhou o sistema solar e disse "A Terra é a nossa casa". Estes relatos evidenciam uma percepção da criança quanto ao deslocamento realizado, e, por meio desses objetos e símbolos, ela passa a dimensionar a rota percorrida. Ademais, observamos o desenvolvimento de sentidos e de significados sobre território e pertencimento. Vale ressaltar que o entorno social em que a criança está inserida é basilar para sua apreensão e representação da realidade. O conteúdo social da atividade também é expresso por meio do desenho, apontando para uma reconstrução criativa dos papéis e das situações vivenciados com outras pessoas. Neste caso em específico, a representação do sistema solar está relacionada à atuação profissional dos pais do menino. Assim, percebemos que a apropriação da realidade concreta se dá pelo aprendizado ativo 
da criança, mas também pela intencionalidade da pessoa adulta que a ensina (RIOS; ROSSLER, 2017), e a atividade criadora da imaginação é sempre baseada nas vivências da criança e apropriações culturais que lhe são oportunizadas (VIGOTSKI, 2018b).

Figura 19: Desenho do sistema solar

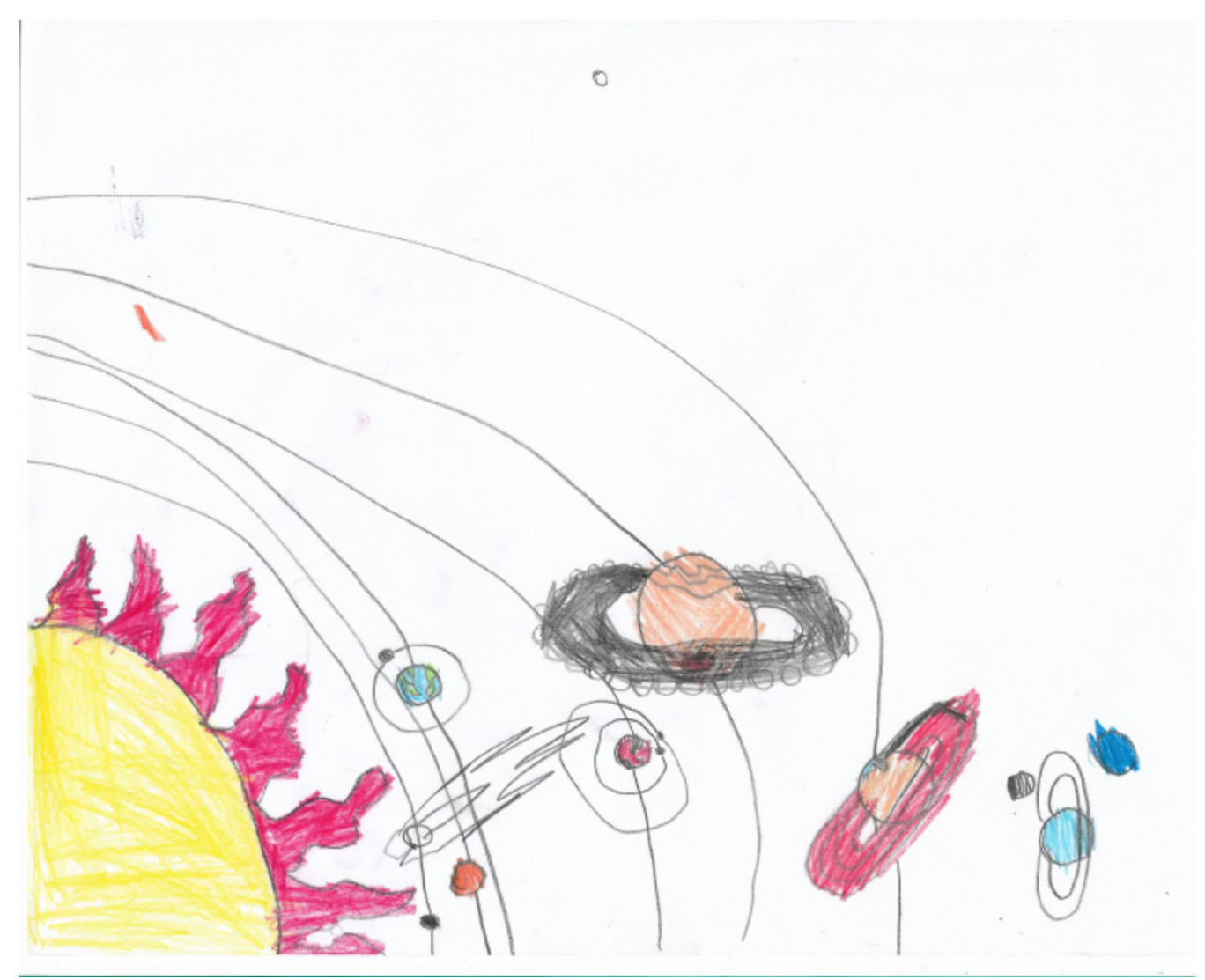

Fonte: Acervo do Pequenos do Mundo, 2019.

\#PraCegoVer: Desenho colorido do Sistema Solar. No canto inferior esquerdo o sol amarelo com raios vermelhos. Linhas formando semicírculos a frente do sol. Oito círculos coloridos de tamanhos diferentes são dispostos sobre as linhas. Alguns possuem anéis, outros possuem satélites.

As memórias das crianças expressam situações, fatos e vivências que as afetam, mobilizam sentimentos e reflexões e possuem significado específico a partir de suas trajetórias singulares. Possibilitar o resgate dessas memórias e oferecer um espaço para o compartilhamento de vivências, permite que as crianças se situem e sejam protagonistas em suas histórias de vida para que, assim, possam compreender de forma mais consciente a si e ao mundo. Além disso, trabalhar o conteúdo da memória, oferecendo possibilidades e mediações constantes para tal, impulsiona o processo de desenvolvimento das crianças Revista X, v. 16, n. 2, p. 485-524, 2021. 
de todas as idades, considerando a interfuncionalidade das funções psicológicas. Nesse processo, consideramos fundamental destacar a importância do envolvimento das famílias, sobretudo do compartilhamento de memórias entre elas e as crianças. Este envolvimento, no contexto da extensão, embora já tenhamos desenvolvido algumas atividades anteriormente, será um ponto de maior atenção em ações futuras. Para Teberosky e Jarque (2015),

[...] as mães que falam do passado de modo mais estruturado e emocional contribuem com a memória autobiográfica mais elaborada e mais acurada de seus filhos, por várias razões: primeiro, porque esse modo conduz a recordações mais organizadas e detalhadas e, portanto, mais acessíveis; segundo, porque recordar o passado de forma minuciosa facilita a compreensão das crianças sobre o tempo e, sobretudo, sobre elas mesmas no tempo (p. 8)

É importante salientar, ainda, que não temos a pretensão de que as crianças desenvolvam habilidades artísticas e tornem-se artistas. É claro que o desenvolvimento de um grande artista depende das mediações que são oferecidas durante sua infância, mas não é nosso foco principal. Nosso objetivo é estimular a atividade criadora das crianças e sua capacidade de serem ativas no mundo e em suas relações. Por meio de atividades planejadas de modo a discutir aspectos da identidade das crianças e de suas vivências - como a rotina, o trajeto migratório -, possibilitamos a elas um espaço de acolhimento e reflexão, coerentes com seu período de desenvolvimento. Com base nesse vínculo e nas mediações artísticas utilizadas, as crianças são capazes de expressar criativamente suas memórias afetivas e os sentidos elaborados sobre os contextos vividos.

Imbuídas dos pressupostos da Psicologia Histórico-Cultural, procuramos dar espaço à expressão das singularidades, do vivido e significado de forma única, mas inserindo essas produções individuais na trama coletiva das vivências com particularidades comuns, historicamente situadas, que atravessam a vida dessas crianças e de suas famílias. A contação de histórias, tal como a utilização de outras formas de produções artísticas, revela-se um recurso importante, pois a compreensão dessas vivências pode ser ampliada, generalizada, na medida em que expõe, direta ou indiretamente, as contradições da realidade humana (ABRANTES, 2016). Assim, desenvolvemos uma proposta e consequentes ações em que as crianças pudessem ouvir histórias, contar as suas, elaborar produções simbólicas e visuais e, nesse processo, se reconhecerem e reconhecerem os outros, tornarem-se conscientes de seu presente e desenvolverem a capacidade de se projetar no futuro. 


\section{CONSIDERAÇÕES FINAIS}

Um princípio norteador para a elaboração das ações do Pequenos do Mundo refere-se à compreensão das especificidades da infância vinculadas às especificidades da migração, como a diversidade cultural, a multiplicidade de costumes, o plurilinguismo e as trajetórias singulares. Apreender como a migração é vivenciada na infância, posta as particularidades dessa época da vida, tornou-se um aspecto central na trajetória do Pequenos do Mundo.

Nesta trajetória, uma das demandas que se manifestou de diferentes modos, tanto pelas crianças quanto por suas famílias, dizia respeito às memórias. Seja pelos relatos de crianças sobre a língua materna, como uma criança venezuelana de três anos que disse não querer esquecer de como se falava o espanhol; seja quando lembravam ou não de danças e músicas típicas do país de origem, como uma criança haitiana de sete anos que disse dançar muito bem Kompa, ou quando um menino, filho de nigerianos, de sete anos disse não saber músicas e cantigas do país de seus pais, ou quando um menino egípcio de 6 anos cantou espontaneamente uma música em sua língua materna a todas as pessoas presentes numa festa de confraternização de final de ano. Seja pelas famílias ao relatarem, incertas e espantadas, que a escola pediu para que não falassem mais na língua materna com a criança para ela se acostumar com o português; ou por enaltecerem a importância do espaço do Pequenos do Mundo, por valorizar a cultura de origem das crianças e permitir que elas tenham contato com outras culturas.

Essas situações, somadas a tantas outras, assinalavam a premência das famílias e das crianças de contarem suas histórias e resgatarem suas memórias. Entendemos que o silenciamento é forma de apagamento da memória, da cultura e da história. Em contraposição a esta prática, cotidiana na vida de migrantes, o trabalho com as memórias afetivas utilizando a arte como recurso se estabeleceu como uma forma de atuação que possibilita às crianças migrantes uma compreensão mais aprofundada de si mesmas e do mundo. Como discutem Braga e Smolka (2020),

[...] olhar para a criança em contexto, compreender cada história de vida, entender como cada uma participa da ambiência cultural na qual se encontra inserida e entretecer e redimensionar as histórias de vida das crianças numa trama coletiva tornam-se fundamentais para o trabalho pedagógico. (p. 188)

Assim, no Pequenos do Mundo, foi necessário o desenvolvimento de uma prática atenta para os impactos da migração no desenvolvimento das crianças, mas que também considere as singularidades de cada criança e de sua história de vida. Foi necessário o Revista X, v. 16, n. 2, p. 485-524, 2021. 
desenvolvimento de uma proposta que ao se voltar ao passado, ao vivido com sentido, direciona-se no presente ao futuro, coloca a vida em perspectiva, ampliando o horizonte.

\section{REFERÊNCIAS}

ABRANTES, A. A. Arte Literária. In: PASQUALINI, J. C. \& TSUHACO, Y. N. (Orgs). Proposta pedagógica para a Educação Infantil do Sistema Municipal de Ensino de Bauru/SP. Bauru: Secretaria Municipal de Educação, 2016.

\section{ALTO COMISSARIADO DAS NAÇÕES UNIDAS PARA REFUGIADOS} (ACNUR). Global trends forced displacement in 2019/2020. Disponível em: https:// www.unhcr.org/globaltrends2019/\#_ga=2.133991046.928147218.16021112652146759819.1602111265. Acesso em: out. 2020.

Manual de procedimentos e de critérios para determinar a condição de refugiado: De acordo com a Convenção de Genebra 1951 e o Protocolo de 1967 relativos ao Estatuto dos Refugiados. ACNUR Brasil, 2004.

BAENINGER, R.; PERES, R. G. Migração de Crise: a migração haitiana para o Brasil. Revista Brasileira de Estudos de População, v. 34, p. 119-143, 2017. Disponível em: https://doi.org/10.20947/s0102-3098a0017. Acesso em: out. 2020.

RODRIGUES, S. M. P.; BERTIZOLI, J. V. F.; PEREZ, F. do R. P.; ANDRÉ, L. A.; ROSSETTO, M. A. V.; DE SOUZA; R. A. D. Artes Visuais. In: PASQUALINI, J. C., TSUHACO, Y. N. (Orgs). Proposta pedagógica para a Educação Infantil do Sistema Municipal de Ensino de Bauru/SP. Bauru: Secretaria Municipal de Educação, 2016.

BRAGA, E. S. O trabalho com a literatura: memórias e histórias. Cad. CEDES, Campinas, v. 20, n. 50, p. 84-102, 2000. Disponível em https://doi.org/10.1590/S010132622000000100007. Acesso em: jun. 2020.

BRAGA, E. S.; SMOLKA, A. L. B. Memória e sentido na narrativa de crianças: inspirações vigotskianas para a pesquisa na escola. Cad. CEDES, Campinas, v. 40, n. 111, p. 185-197, 2020. Disponível em http://dx.doi.org/10.1590/cc231666. Acesso em: ago. 2020.

CAMPANO, G. Immigrant Students and Literacy: Reading, Wrinting and Remembering. Nova York: Teachers College Press, 2007.

CHAVES, M. Arte e Literatura na Educação Infantil: Realizações Humanizadoras com Crianças e Educadores, 2009. 
COMITÊ NACIONAL PARA OS REFUGIADOS (CONARE). Ministério da Justiça e Segurança Pública. Refúgio em números. Brasília, 4a ed, 2019. Disponível em: https:// www.justica.gov.br/seus-direitos/refugio/refugio-em-numeros. Acesso em: set. 2020.

CURSINO, C.; ALBUQUERQUE, J.; FIGUEIREDO SILVA, M.C.; GABRIEL, M.; ANUNCIAÇÃO, R.F.M. Português Brasileiro para Migração Humanitária (PBMIH): reflexões linguísticas e pedagógicas para o ensino de PLE em contexto de migração e refúgio. In: RUANO, B.P.; SANTOS, J. P.; SALTINI, L. (orgs.) Cursos de Português como Língua Estrangeira no Celin-UFPR: práticas docentes e experiências em sala de aula. Curitiba: Editora UFPR, 2016, p. 317-334. Disponível em: https://bit.ly/2SfIJWj

DEMARTINI, Z. B. F. Infância e imigração: questões para pesquisa. In: FREITAS, M. C. de (Org.). Desigualdade social e diversidade cultural na infância e na juventude. São Paulo: Cortez, 2006. p. 113-153.

DEMARTINI, Z. B. F. Diferentes infâncias, diferentes questões para a pesquisa. In: MARTINS FILHO, A. J.; PRADO, P. D. (Org.). Das pesquisas com crianças à complexidade da infância. Campinas, SP: Autores Associados, 2011. p. 11-25.

GARLAND, S. Um outro país para Azzi. São Paulo: Editora Pulo do Gato, 2012.

LEONTIEV, A. N. Uma contribuição à teoria do Desenvolvimento da Psique Infantil. In: VYGOTSKI, L.S.; LURIA, A.R.; LEONTIEV, A.N. Linguagem, Desenvolvimento e Aprendizagem. São Paulo: Ícone, Ed. USP, 1988.

LURIA, A. R. Curso de Psicologia Geral: atenção e memória. v. III. Rio de Janeiro: Ed. Civilização Brasileira, 1994.

MARTIN-BARÓ, I. O papel do Psicólogo. Estud. psicol. (Natal), v. 2, n. 1, p. 7-27, 1997. Disponível em: http://dx.doi.org/10.1590/S1413-294X1997000100002. Acesso em: abr. 2020.

MARTINS-BORGES, L; JIBRIN, M; BARROS, A, F, O. Clínica intercultural: a escuta da diferença. Contextos Clínicos, v. 8, n. 2, p. 186-192, 2015. Disponível em http://dx.doi. org/10.4013/ctc.2015.82.07. Acesso em: out. 2020.

MARTINS, L. M. O desenvolvimento do psiquismo e a educação escolar: contribuições à luz da psicologia histórico-cultural e da pedagogia histórico-crítica. Campinas: Autores Associados, 2013.

MARTINS, L. M.; CARVALHO, B. A atividade humana como unidade afetivo-cognitiva: um enfoque histórico-cultural. In: Psicologia em Estudo, v. 21, n. 4, p. 699-710, 2016. Disponível em: https://doi.org/10.4025/psicolestud.v21i4.32431. Acesso em: 28 jul. 2020. 
NASCIMENTO, C. P.; PASQUALINI, J. C. Arte. In: PASQUALINI, J. C.; TSUHACO, Y. N. (Org). Proposta pedagógica para a Educação Infantil do Sistema Municipal de Ensino de Bauru/SP. Bauru: Secretaria Municipal de Educação, 2016.

ORGANIZAÇÃO INTERNACIONAL PARA AS MIGRAÇÕES (OIM). Informe sobre las migraciones en el mundo 2020. 2019. Disponível em: https://publications.iom.int/ system/files/pdf/iml22.pdf. Acesso em: 2 jul. 2020.

PARAGUASSU, F. A menina que abraça o vento. Curitiba, PR: Editora Vooinho, 2017.

PASQUALINI, J. C.; EIDT, N. M. Periodização do desenvolvimento infantil e ações educativas. In: PASQUALINI, J. C.; TSUHAKO, Y. N. Proposta pedagógica para a Educação Infantil do Sistema Municipal de Ensino de Bauru/SP [recurso eletrônico]. Bauru: Secretaria Municipal de Educação, 2016.

RIOS, C. F. M.; ROSSLER, J. H. Atividade principal e periodização do desenvolvimento psíquico: contribuições da psicologia histórico-cultural para os processos educacionais. Perspectivas en Psicología, v. 14, n. 2, 2017, p. 30-41. Disponível em http://200.0.183.216/ revista/index.php/pep/article/view/319. Acesso em: ago. 2020.

UNITED NATIONS CHILDREN'S FUND (UNICEF). Child Migration and refugees. Disponível em: https://data.unicef.org/topic/child-migration-and-displacement/migration. Acesso em: 28 jul. 2020.

VIGOTSKI, L. S. El problema de la edad. In: VIGOTSKI, L. S. Obras Escogidas. Tomo IV. Visor: Madrid, 1996. p. 251-273.

. Arte e vida. In: VIGOTSKI, L. S. Psicologia da Arte. São Paulo: Martins Fontes, 1999, p. 303-329.

. Sobre a questão do multilinguismo na infância. Revista digital Teias. Rio de Janeiro, ano 6, n. 11-12, p. 1-5, jan./dez. 2005.

Quarta aula: o problema do meio na pedologia. In: VIGOTSKI, L. S. Sete aulas de Vigotski sobre os fundamentos da pedologia. Organização [e tradução] Zoia Prestes, Elizabeth Tunes; tradução de Claudia da C. G. Santana. Rio de Janeiro: E-papers, 2018a. p. 73-92.

Imaginação e Criação na infância. São Paulo, SP: Expressão Popular, 2018 b.

Recebido em: 12 out. 2020.

Aceito em: 11 mar. 2021. 